\title{
Dynamic evaluation of a multi-year model simulation of particulate matter concentrations over Europe
}

\author{
È. Lecour and C. Seigneur \\ CEREA, Joint Laboratory École des Ponts ParisTech/EDF R\&D, Université Paris-Est, 77455 Marne-la-Vallée, France \\ Correspondence to: È. Lecœur (eve.lecoeur@cerea.enpc.fr)
}

Received: 9 November 2012 - Published in Atmos. Chem. Phys. Discuss.: 8 January 2013

Revised: 25 March 2013 - Accepted: 4 April 2013 - Published: 25 April 2013

\begin{abstract}
A $9 \mathrm{yr}$ air quality simulation is conducted from 2000 to 2008 over Europe using the Polyphemus/Polair3D chemical-transport model (CTM) and then evaluated against the measurements of the European Monitoring and Evaluation Programme (EMEP).

The spatial distribution of $\mathrm{PM}_{2.5}$ over Europe shows high concentrations over northern Italy $\left(36 \mu \mathrm{g} \mathrm{m}^{-3}\right)$ and some areas of Eastern Europe, France, and Benelux, and low concentrations over Scandinavia, Spain, and the easternmost part of Europe. $\mathrm{PM}_{2.5}$ composition differs among regions.

The operational evaluation shows satisfactory model performance for ozone $\left(\mathrm{O}_{3}\right) . \mathrm{PM}_{2.5}, \mathrm{PM}_{10}$, and sulfate $\left(\mathrm{SO}_{4}^{=}\right)$ meet the performance goal of Boylan and Russell (2006). Nitrate $\left(\mathrm{NO}_{3}^{-}\right)$and ammonium $\left(\mathrm{NH}_{4}^{+}\right)$are overestimated, although $\mathrm{NH}_{4}^{+}$meets the performance criterion. The correlation coefficients between simulated and observed data are $63 \%$ for $\mathrm{O}_{3}, 57 \%$ for $\mathrm{PM}_{10}, 59 \%$ for $\mathrm{PM}_{2.5}, 57 \%$ for $\mathrm{SO}_{4}^{=}$, $42 \%$ for $\mathrm{NO}_{3}^{-}$, and $58 \%$ for $\mathrm{NH}_{4}^{+}$. The comparison with other recent $1 \mathrm{yr}$ model simulations shows that all models overestimate nitrate. The performance of $\mathrm{PM}_{2.5}$, sulfate, and ammonium is comparable to that of the other models.

The dynamic evaluation shows that the response of $\mathrm{PM}_{2.5}$ to changes in meteorology differs depending on location and the meteorological variable considered. Wind speed and precipitation show a strong negative day-to-day correlation with $\mathrm{PM}_{2.5}$ and its components (except for sea salt, which shows a positive correlation), which tends towards 0 as the day lag increases. On the other hand, the correlation coefficient is near constant for temperature, for any day lag and $\mathrm{PM}_{2.5}$ species, but it may be positive or negative depending on the species and, for sulfate, depending on the location. The effects of precipitation and wind speed on $\mathrm{PM}_{2.5}$ and its components are better reproduced by the model than the effects of tem-
\end{abstract}

perature. This is mainly due to the fact that temperature has different effects on the $\mathrm{PM}_{2.5}$ components, unlike precipitation and wind speed, which impact most of the $\mathrm{PM}_{2.5}$ components in the same way.

These results suggest that state-of-the-science air quality models reproduce satisfactorily the effect of meteorology on $\mathrm{PM}_{2.5}$ and therefore are suitable to investigate the effects of climate change on particulate air quality, although uncertainties remain concerning semivolatile $\mathrm{PM}_{2.5}$ components.

\section{Introduction}

Atmospheric particulate matter (PM) pollution has become a field of great interest because of its impacts on human health, climate change, and atmospheric visibility. Therefore, air quality regulations have been implemented for PM concentrations. In particular, fine particles with an aerodynamic diameter less than or equal to $2.5 \mu \mathrm{m}\left(\mathrm{PM}_{2.5}\right)$ are regulated in North America and Europe as a consequence of their effects on human health (respiratory and cardiovascular diseases). $\mathrm{PM}_{2.5}$ is a complex mixture of particles of different sizes and chemical compositions. These chemical compositions include primary PM, which is directly emitted in the atmosphere from various sources (e.g., road traffic, construction sites, soil dust, fires), and secondary PM, which is formed in the atmosphere via chemical reactions in the gas and aqueous phases, leading to the oxidation of precursors such as sulfur dioxide $\left(\mathrm{SO}_{2}\right)$, nitrogen oxides $\left(\mathrm{NO}_{\mathrm{x}}\right)$, and volatile organic compounds (VOC) to nonvolatile and semivolatile species. The processes that govern the secondary particle concentrations are various and complex. In particular, they depend strongly on meteorology (temperature, solar radiation, 
humidity, presence of clouds and fog). Emissions of primary particles and precursors of secondary PM are also strongly affected by meteorology (wind speed, temperature, solar radiation). Furthermore, precipitation removes PM from the atmosphere. Therefore, climate change is expected to affect PM concentrations via the effect of meteorological variables on the emissions, formation, and removal of PM.

Studies of the effect of climate change on air quality have focused initially on ozone (e.g., Meleux et al., 2007; Loon et al., 2007; Mahmud et al., 2008; Wu et al., 2008; Chen et al., 2009; Katragkou et al., 2011), and the study of its effect on PM concentrations is more recent. So far, most of the PM studies have focused on the United States and, to a lesser extent, Europe (e.g., Racherla and Adams, 2006; Dawson et al., 2007, 2009; Zhang et al., 2008; Avise et al., 2009; Pye et al., 2009; Tagaris et al., 2009; Mahmud et al., 2010; Singh and Palazoglu, 2012; Tai et al., 2010, 2012; Kelly et al., 2012), but simulations have typically been limited to a year or several months. The individual effects of various meteorological variables have been examined for the United States by perturbing each meteorological variable separately. The results suggest that the strongest effects of changes in meteorology on $\mathrm{PM}_{2.5}$ concentrations are the effects of temperature, wind speed, absolute humidity, mixing height, and precipitation. According to these studies (Dawson et al., 2007; Mahmud et al., 2010; Galindo et al., 2011), temperature tends to increase average sulfate concentrations and decrease average nitrate and organic concentrations, leading to an overall decrease in $\mathrm{PM}_{2.5}$ concentrations. Increasing absolute humidity increases nitrate aerosol, which leads to increased $\mathrm{PM}_{2.5}$ concentrations. Changes in mixing height lead to mixing and dilution effects, with $\mathrm{PM}_{2.5}$ concentrations generally decreasing as mixing height increases. $\mathrm{PM}_{2.5}$ concentrations decrease with increased precipitation rate and the extent of the precipitation area. Increases in wind speed lead to changes in advection and transport resulting in decreases in $\mathrm{PM}_{2.5}$ concentrations. Because meteorology may affect $\mathrm{PM}_{2.5} \mathrm{com}-$ ponents in opposite ways (e.g., an increase in temperature favors the emissions of biogenic VOC and their oxidation to semivolatile organic compounds (SVOC) but increases SVOC volatility), no strong consensus has yet been reached on the effects of the overall present and future climate on $\mathrm{PM}_{2.5}$ concentrations. To date, there have only been a few studies about the effect of climate on $\mathrm{PM}_{2.5}$ over Europe, as a consequence of the limited amount of daily $\mathrm{PM}_{2.5}$ observations. Nevertheless, some observations provide also $\mathrm{PM}_{2.5}$ chemical composition, which is important to understand the effect of meteorology on $\mathrm{PM}_{2.5}$, thus the present study focuses on $\mathrm{PM}_{2.5}$.

Before one investigates the effects of climate change on PM concentrations, it is primordial to ensure that our current understanding of the relationships between meteorology and PM concentrations is correct. Typically, the evaluation of model performance is limited to the ability of the model to reproduce $\mathrm{PM}_{2.5}$ and its components and provides no in- formation on the ability of a model to predict the response of $\mathrm{PM}_{2.5}$ components to changes in meteorology. Four levels of model performance evaluation may be considered: operational, diagnostic, dynamic, and probabilistic (Seigneur et al., 2000; Dennis et al., 2010). The operational evaluation tests the ability of the model to correctly estimate PM concentrations, while the diagnostic evaluation focuses on the estimation of the components of PM and precursors (Dennis et al. (2010) included PM components in the operational evaluation and we follow their categorization here for simplicity). The dynamic evaluation tests the ability of the model to predict the response of PM concentrations to changes in meteorology and emissions. Finally, the probabilistic evaluation takes also into account the uncertainties associated with the model predictions and observations of PM. To date, dynamic model performance evaluations have been limited to emission changes of ozone $\left(\mathrm{O}_{3}\right)$ precursors over the United States (e.g., Gilliland et al., 2008; Yarwood et al., 2003) and to the response of $\mathrm{O}_{3}$, nitrogen dioxide $\left(\mathrm{NO}_{2}\right)$, and $\mathrm{PM}_{10}$ over Europe (Colette et al., 2011). To our knowledge, there has been no comprehensive dynamic evaluation conducted with respect to meteorology. Therefore, the goal of this study is to conduct such a dynamic evaluation using a multi-year simulation of $\mathrm{PM}_{2.5}$ over Europe. Such an assessment of model performance appears needed since air quality models are increasingly being used to investigate the effect of climate change on future PM concentrations.

A brief description of the Polyphemus/Polair3D modeling system used here is given in Sect. 2, along with the characteristics of the model simulation and the spatial distribution and composition of modeled $\mathrm{PM}_{2.5}$. The Polyphemus system is used for simulating concentrations over Europe for years 2000 to 2008. An evaluation is then made for each year for both gases and aerosols. An operational model performance evaluation using available data is presented in Sect. 3. Those results are compared with those obtained recently in the AQMEII project and in other $1 \mathrm{yr}$ model performance evaluations for $\mathrm{PM}_{10}, \mathrm{PM}_{2.5}$ and its components. A dynamic evaluation performed with respect to meteorology is presented in Sect. 4. Conclusions and future prospects are presented in Sect. 5 .

\section{Model simulation}

\subsection{Input data and model configuration}

We used the Polyphemus/Polair3D model (Mallet et al., 2007; Debry et al., 2007; Sartelet et al., 2007; Couvidat et al., 2012) to simulate $9 \mathrm{yr}$ (2000-2008) of concentrations of gaseous and particulate pollutants over Europe. Polyphemus is an air quality modeling platform that has been used for many applications at different scales (from local to continental). Polair3D is the chemical-transport model (CTM) of Polyphemus. 
The modeling domain covers a geographical area that spreads from $15^{\circ} \mathrm{W}$ to $34.5^{\circ} \mathrm{E}$ in longitude and from $35^{\circ} \mathrm{N}$ to $69.5^{\circ} \mathrm{N}$ in latitude. Therefore, the domain covers an area of $100^{\circ} \times 70^{\circ}$ with a step of $0.5^{\circ}$ along both longitude and latitude, as shown in Fig. 1. Fourteen levels are considered from the ground up to $12000 \mathrm{~m}$. The boundary heights of the different model layers are 30,60, 100, 150, 200, 300, 500, $750,1000,1500,2400,3500,6000$, and $12000 \mathrm{~m}$.

Meteorological data were obtained from the reanalyses of the European Centre for Medium-Range Weather Forecasts (ECMWF). The horizontal resolution (both longitude and latitude) for specific years of these meteorological fields is $1.125^{\circ}$ for $2000,0.36^{\circ}$ for $2001-2005$, and $0.25^{\circ}$ for $2006-$ 2008. The vertical resolution includes 36 levels for 2000 2002, 2005, and January 2006, 31 levels for 2003-2004, and 54 levels for the remainder of 2006 and 2007-2008.

Anthropogenic emissions for gases and particles were generated with the Environmental Monitoring and Evaluation Programme $^{1}$ (EMEP) inventory for 2000 to 2008 for all sectors. Surface emissions were directly injected into the model surface layer and elevated point source emissions were injected into the model layers following the EMEP table for vertical distribution. No horizontal disaggregation was needed because the model and EMEP inventory have similar grid spacings. Temporal profiles by source sectors provided by EMEP were used. Biogenic emissions were computed with the Model of Emissions of Gases and Aerosols from Nature (MEGAN, Guenther et al., 2006). $\mathrm{NO}_{\mathrm{x}}$ from soils was excluded from SNAP10 of the EMEP inventory to avoid double counting. Sea salt emissions are parameterized following Monahan et al. (1986). Forest fire emissions were not considered as they were not available. Moreover, modeling the impact of forest fires is still an area of research due to uncertainties in emission rates and smoke plume heights.

The chemical mechanism chosen for the simulation is CB05 (Yarwood et al., 2005). It has been shown to perform satisfactorily in previous applications to Europe (Kim et al., 2009).

Boundary conditions are obtained from the outputs of the Model of Ozone And Related Tracers (MOZART-4, Emmons et al., 2010) for the years 2004 to 2008, with $6 \mathrm{~h}$ resolution. No MOZART output is available for years 2000 to 2002, and the year 2003 is incomplete; we thus computed the mean of years 2004 to 2008 to create climatological boundary conditions for years 2000-2003. The year 2004 alone could have been considered for those boundary conditions since emission control policies led to decreases in emissions in Europe and North America over the period of interest. However, boundary conditions depend also on meteorology, and a mean over $5 \mathrm{yr}$ provides more robustness. The MOZART-4 chemical mechanism includes 85 gas-phase species, 12 bulk aerosol compounds, 39 photolysis and 157 thermal gas-phase reactions. Dust and sea salt aerosol data are distributed in

\footnotetext{
${ }^{1}$ http://emep.int/
}

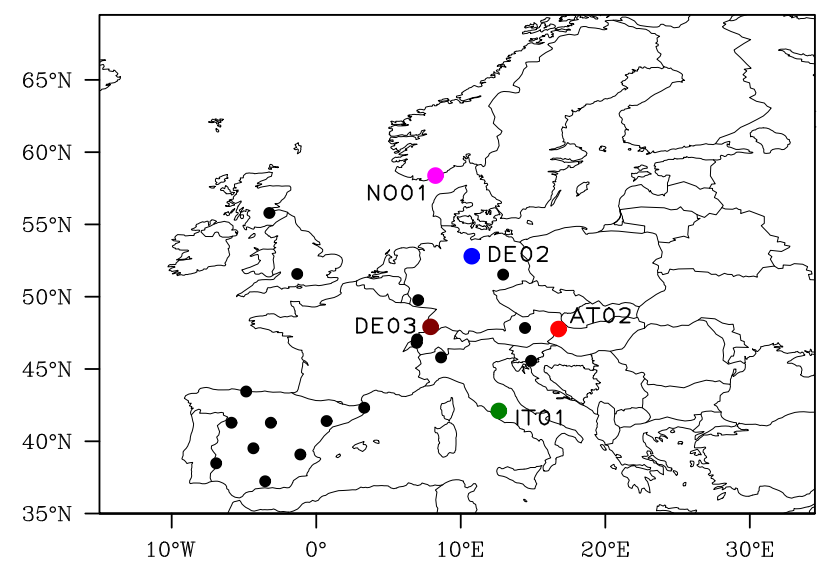

Fig. 1. Geographical domain of the simulation and EMEP stations used for the dynamic evaluation (Sect. 4). The stations with a colored dot provide data for $\mathrm{PM}_{2.5}$, sulfate, nitrate, and ammonium, while those with a black dot only provide $\mathrm{PM}_{2.5}$ data.

MOZART4 among four size sections (0.05-0.5, 0.5-1.25, $1.25-2.5$, and $2.5-5.0 \mu \mathrm{m}$ for dust and $0.1-0.5,0.5-1.5,1.5-$ 5.0 , and $5.0-10.0 \mu \mathrm{m}$ for sea salt). The concentrations from the input data are proportionally redistributed among the five sections of Polair3D (0.01-0.04, 0.04-0.16, 0.16-0.63, 0.632.5, and 2.5-10.0 $\mu \mathrm{m})$. Black carbon, organic carbon, nitrate, ammonium, and sulfate aerosol input data follow a normal size distribution, which is distributed over the five sections of Polair3D. We used 60 species from MOZART-4 in the boundary conditions. The MOZART-4 VOC species were matched to CB05 following information available in Emmons et al. (2010). For example, BIGALK is considered as ALK3 and thus matched to 3.0 PAR, BIGENE to 1.0 PAR + 1.0 OLE, and TOLUENE to TOL (instead of a combination of TOL and XYL). The aerosol species were also matched to Polair3D species. Most of the species were directly matched to Polair3D, except $\mathrm{OC} 1$ and $\mathrm{OC} 2$, which were converted to 2.25 PSOAIP + 2.88 PSOAmP + 3.87 PSOAhP. These coefficients, which depend on the SVOC/POA and OM/OC ratios are taken from Couvidat et al. (2013).

Photolysis rates are computed offline using the photolysis preprocessor Fast-J, which calculates photolysis rates in the presence of an arbitrary mix of cloud and aerosol layers (Wild et al., 2000). The dynamics of the PM size distribution is simulated according to a sectional representation of the PM mass distribution (Debry et al., 2007). Aerosol dynamics (coagulation, nucleation, condensation, and evaporation) is treated. Inorganic PM is simulated with the ISORROPIA thermodynamic model (Nenes et al., 1998) and organic PM is modeled with a hydrophilic/hydrophobic organic $\left(\mathrm{H}^{2} \mathrm{O}\right)$ model using a molecular surrogate approach (Couvidat et al., 2012). Nitrate aerosol in the coarse fraction is treated. The dry deposition velocities for gases are preprocessed with the parameterization of Zhang et al. (2003). Vertical diffusion is 
computed using the Troen and Mahrt (1986) parameterization within the planetary boundary layer. For land use coverage, the United States Geological Survey (USGS) cover map is used. For each year of simulation, the initial conditions are computed by using a spin-up period of 15 days from 15 to 31 December of the previous year.

\section{2 $\quad \mathrm{PM}_{2.5}$ spatial distribution and chemical composition over Europe}

The spatial distribution of particulate species over Europe is shown in Fig. 2 for the $9 \mathrm{yr}$ averaged surface concentrations of $\mathrm{PM}_{2.5}$, sulfate, nitrate, ammonium, sea salt, organic matter, black carbon, and mineral dust. Figure 2a shows high concentrations of $\mathrm{PM}_{2.5}$ over northern Italy $\left(36 \mu \mathrm{g} \mathrm{m}^{-3}\right)$, the Netherlands $\left(25 \mu \mathrm{g} \mathrm{m}^{-3}\right)$, northeastern Spain and France, and Eastern European countries (around $22 \mu \mathrm{g} \mathrm{m}^{-3}$ ), while concentrations are lower in the northern and easternmost parts of Europe and in Spain (between 4 and $14 \mu \mathrm{g} \mathrm{m}^{-3}$ ). Figure $2 \mathrm{~b}$ depicts higher concentrations of sulfate over Eastern Europe, with two peaks in Romania and Bulgaria $\left(5.5 \mu \mathrm{g} \mathrm{m}^{-3}\right)$ and a general south-north gradient and a land-ocean gradient. Figure $2 \mathrm{c}$ shows high concentrations of nitrate at the center of the domain (up to $12 \mu \mathrm{g} \mathrm{m}^{-3}$ over northern Italy), while low concentrations are less than $4 \mu \mathrm{g} \mathrm{m}^{-3}$ over the rest of the continent. High concentrations of ammonium are localized in northern Italy, Benelux, and southern Poland (Fig. 2d), with a maximum of $5 \mu \mathrm{g} \mathrm{m}^{-3}$ in the Milan area. As expected, sea salt concentrations are highest over the Atlantic Ocean (between 4 and $7 \mu \mathrm{g} \mathrm{m}^{-3}$ ), the Mediterranean Sea and the Baltic Sea (between 2.5 and $4 \mu \mathrm{g} \mathrm{m}^{-3}$ ), and along the coasts of the countries bordering the sea and the ocean (between 2 and $3 \mu \mathrm{g} \mathrm{m}^{-3}$ ). Sea salt concentrations are near zero on the continent (Fig. 2e). There is a sea salt gradient in the northwestern part of the domain, which is a consequence of two factors: high sea salt emissions in this part of the domain, and different parameterizations used in the model computation of sea salt emissions (Monahan et al., 1986) and in the boundary conditions (Mahowald et al., 2006). $\mathrm{PM}_{2.5}$ organic matter concentrations are high in northwestern Portugal, eastern France, and over northern Italy (between 8.5 and $13 \mu \mathrm{g} \mathrm{m}^{-3}$ ). Slovenia, Poland, and Romania also show high concentrations of organic matter (around $8 \mu \mathrm{g} \mathrm{m}^{-3}$ ) (Fig. 2f). As expected, there is an ocean-land gradient since both anthropogenic and biogenic emissions are higher on land than over water due to the presence of vegetation and human activities. Black carbon concentrations are below $1 \mu \mathrm{g} \mathrm{m} \mathrm{m}^{-3}$ over all of Europe, except for the northeastern part of France $\left(3 \mu \mathrm{g} \mathrm{m}^{-3}\right)$ and in some localized areas in France, Italy, and Romania $\left(1.25 \mu \mathrm{g} \mathrm{m}^{-3}\right)$ (Fig. $2 \mathrm{~g}$ ). The concentrations of mineral dust vary from 1.5 to $5 \mu \mathrm{g} \mathrm{m}^{-3}$ below $52^{\circ} \mathrm{N}$, while they vary from 0.75 to $1.5 \mu \mathrm{g} \mathrm{m}^{-3}$ above $52^{\circ} \mathrm{N}$.

Figure 3 presents the $9 \mathrm{yr}$ averaged surface fractions of sulfate, nitrate, ammonium, sea salt, organic matter, black carbon, and mineral dust in $\mathrm{PM}_{2.5}$. In Scandinavia, $\mathrm{PM}_{2.5}$ con-

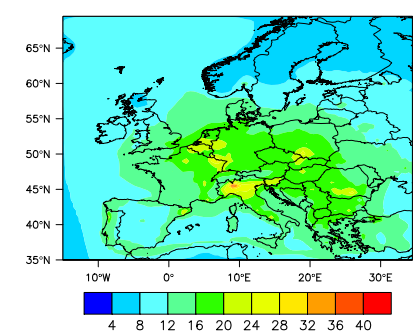

(a) $\mathrm{PM}_{2.5}$

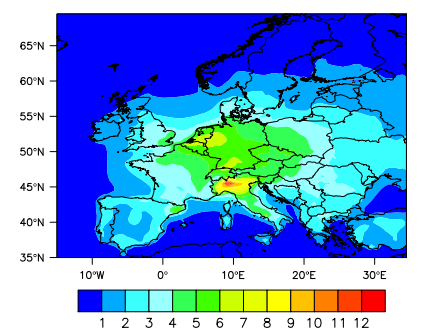

(c) Nitrate

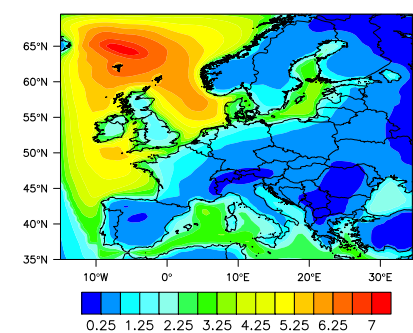

(e) Sea salt

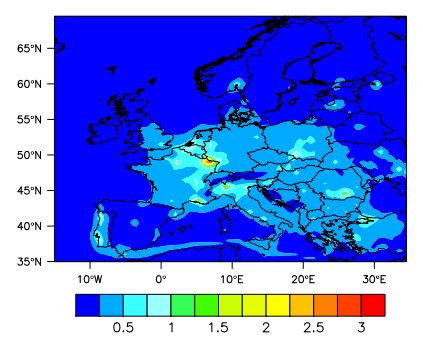

(g) Black carbon

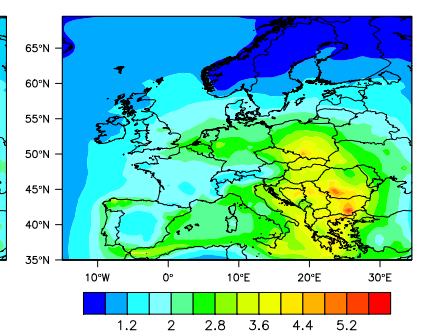

(b) Sulfate

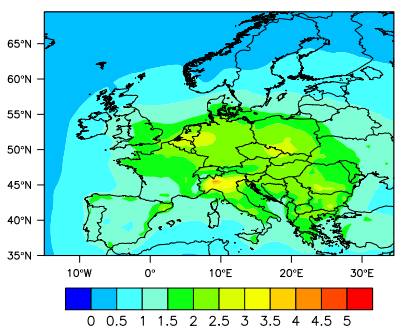

(d) Ammonium

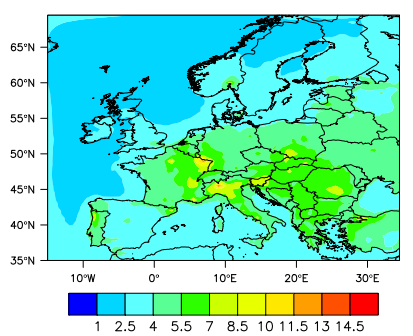

(f) Organic matter

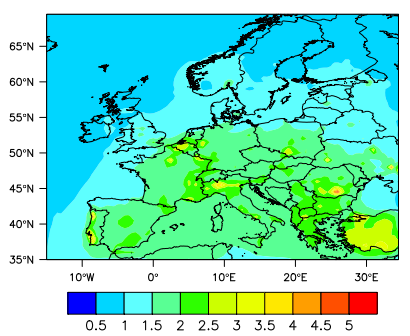

(h) Mineral dust
Fig. 2. Nine-year (2000-2008) averaged surface concentrations of $\mathrm{PM}_{2.5}$ and its components, expressed in $\mu \mathrm{g} \mathrm{m}{ }^{-3}$.

sists mainly of mineral dust (from $14 \%$ to $20 \%$ ), nitrate for the southernmost (and most industrial) part of Scandinavia (12 to $30 \%$ ), and organic matter (from $40 \%$ to $60 \%$ ). The MEGAN emissions show high monoterpene emissions over Scandinavia, which, combined with the low pollution in this region, explain the high fraction of organic matter in $\mathrm{PM}_{2.5}$. Nitrate, ammonium, and organic matter account for around $60 \%$ of $\mathrm{PM}_{2.5}$ in Germany, Switzerland, Austria, and northern Italy, while sulfate and mineral dust represent together around $20 \%$.

As expected, $\mathrm{PM}_{2.5}$ is mainly sea salt over the ocean and the sea (from $22 \%$ to $60 \%$ of its composition); $\mathrm{PM}_{2.5}$ along the west coast of France, Ireland, Great Britain, the Netherlands, and Denmark is around $20 \%$ sea salt. Organic matter 


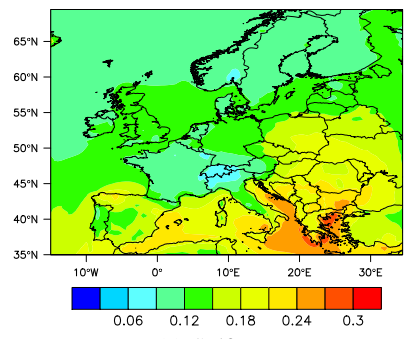

(a) Sulfate

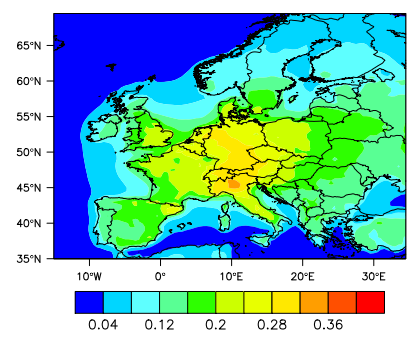

(b) Nitrate

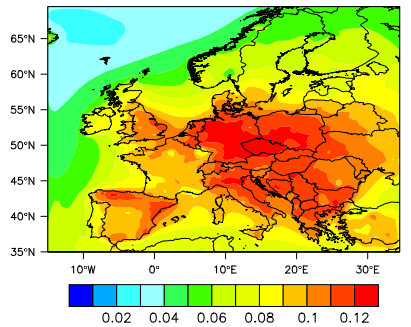

(c) Ammonium

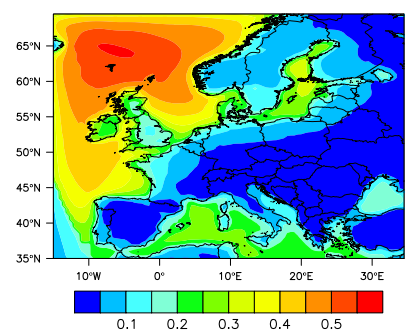

(d) Sea salt

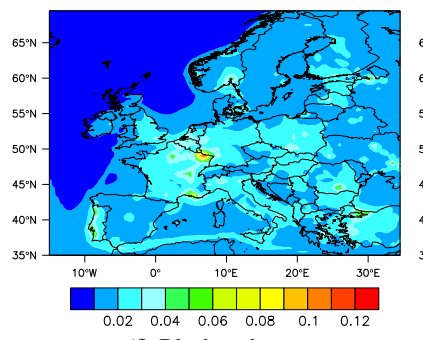

(f) Black carbon

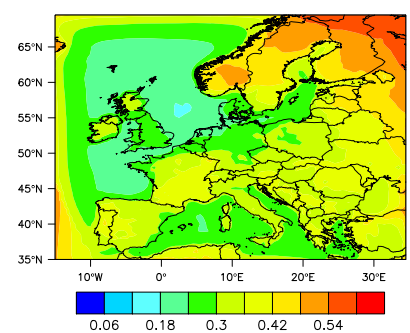

(e) Organic matter

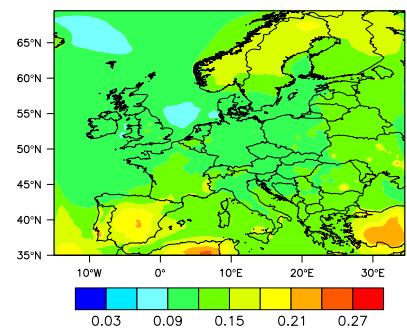

(g) Mineral dust
Fig. 3. Nine-year (2000-2008) averaged surface fractions of sulfate, nitrate, ammonium, sea salt, organic matter, black carbon, and mineral dust in $\mathrm{PM}_{2.5}$.

represents around $20 \%$ in Germany, Belgium, southeastern England, and northwestern France, and from $30 \%$ to $50 \%$ in the rest of Europe. Black carbon accounts for less than $4 \%$ in all of Europe, except for some localized areas in Portugal, France, Romania, and Turkey ( $4 \%$ to $8 \%$ ) as well as a peak of $10 \%$ that is observed at the border of France with Luxembourg and Germany.

\section{Operational evaluation}

\subsection{Statistical scores}

The operational evaluation was performed for each year for ozone $\left(\mathrm{O}_{3}\right)$ and PM. Available PM measurements include $\mathrm{PM}_{10}$ and $\mathrm{PM}_{2.5}$ mass concentrations and $\mathrm{PM}_{2.5}$ sulfate $\left(\mathrm{SO}_{4}^{-}\right)$, nitrate $\left(\mathrm{NO}_{3}^{-}\right)$, and ammonium $\left(\mathrm{NH}_{4}^{+}\right)$concentrations. Although organic carbon and elemental carbon data are available at the EMEP stations for $1 \mathrm{yr}$ (Yttri et al., 2007), no operational evaluation was performed for these species as Polair3D has recently been evaluated for carbonaceous species (Couvidat et al., 2012). The correlation coefficient (\%) and the root-mean-square error (RMSE) $\left(\mu \mathrm{g} \mathrm{m}^{-3}\right)$ are presented in Table 1 to provide a common overview of model performance for $\mathrm{O}_{3}$ and PM. Other statistical metrics that are used routinely to evaluate model performance are presented in Table 2. The model fits best to the observations when the RMSE is small compared to the observed mean and the correlation coefficient is large. The U.S. EPA (EPA, 1991; Russell and Dennis, 2000) recommends using the mean normalized bias (MNB) (\%) and the mean normalized error (MNE) (\%) with an observation-based minimum threshold of about 80-120 $\mu \mathrm{g} \mathrm{m}^{-3}$ to evaluate hourly $\mathrm{O}_{3}$. A threshold of $80 \mu \mathrm{g} \mathrm{m}^{-3}$ was used here. The suggested performance criteria are $|\mathrm{MNB}| \leq$ $15 \%$ and $\mathrm{MNE} \leq 35 \%$. Bias indicates whether the model tends to under or overpredict the observations, and error and RMSE indicate how much it deviates from the observations. The mean fractional bias (MFB) $(\%)$ and the mean fractional error (MFE) (\%) are recommended to evaluate PM (Boylan and Russell, 2006). The model performance goal is met when both MFE and $|\mathrm{MFB}|$ are less than or equal to $50 \%$ and $30 \%$, respectively, and the model performance criterion is met when both MFE $\leq 75 \%$ and $|\mathrm{MFB}| \leq 60 \%$.

The total number of stations that provide data for at least $1 \mathrm{yr}$ in the whole period is 91 for $\mathrm{O}_{3}, 77$ for $\mathrm{SO}_{4}^{=}, 34$ for $\mathrm{NH}_{4}^{+}, 33$ for $\mathrm{NO}_{3}^{-}$and $\mathrm{PM}_{10}$, and 22 for $\mathrm{PM}_{2.5}$. If the number of stations for which data are available each year is about constant for $\mathrm{O}_{3}$ (around 70 stations), $\mathrm{SO}_{4}^{=}$(around 20 stations), and $\mathrm{PM}_{10}$ (around 10 stations), that number is more variable for the other species. For example, 20 stations provide data for $\mathrm{PM}_{2.5}$ in 2005, while there are only 2 in 2000. There are some uncertainties in the observational data. Although most of the sites are remote rural background stations, they could nevertheless be impacted by some proximate source or be affected by local meteorological conditions that are not resolved by the model (representativeness issue). Moreover, artifacts associated with $\mathrm{NO}_{3}^{-}$and $\mathrm{NH}_{4}^{+}$ measurements occur due to evaporation (or condensation) of semivolatile ammonium nitrate $\left(\mathrm{NH}_{4} \mathrm{NO}_{3}\right)$ from the particles collected on the filter due to fluctuations in temperature and relative humidity and/or pressure drop across the filter, which perturb the gas-particle equilibrium. In California these uncertainties have been estimated to be up to $30 \%$ (Hering and Cass, 1999); however, they could be less 
Table 1. Temporal correlations between the simulated and observed data ( $\rho$, expressed in $\%)$, RMSE, mean of the observations $\left(\mu_{\mathrm{obs}}\right)$ and of the simulation $\left(\mu_{\mathrm{sim}}\right)$ (expressed in $\mu \mathrm{g} \mathrm{m}^{-3}$ ) for $\mathrm{O}_{3}$ (hourly basis), $\mathrm{PM}_{10}, \mathrm{PM}_{2.5}, \mathrm{SO}_{4}^{=}, \mathrm{NO}_{3}^{-}$, and $\mathrm{NH}_{4}^{+}$(daily basis).

\begin{tabular}{|c|c|c|c|c|c|c|c|c|c|c|c|c|}
\hline \multirow[b]{2}{*}{ Year } & \multicolumn{4}{|c|}{$\mathrm{O}_{3}$} & \multicolumn{4}{|c|}{$\mathrm{PM}_{10}$} & \multicolumn{4}{|c|}{$\mathrm{PM}_{2.5}$} \\
\hline & $\rho$ & RMSE & $\mu_{\mathrm{obs}}$ & $\mu_{\text {sim }}$ & $\rho$ & RMSE & $\mu_{\mathrm{obs}}$ & $\mu_{\text {sim }} \mid$ & $\rho$ & RMSE & $\mu_{\mathrm{obs}}$ & $\mu_{\text {sim }}$ \\
\hline 2000 & 61.6 & 34.1 & 58.8 & 80.2 & 59.5 & 13.0 & 16.1 & 24.7 & 51.1 & 13.0 & 13.6 & 22.3 \\
\hline 2001 & 64.0 & 28.6 & 56.0 & 74.0 & 61.0 & 9.9 & 18.0 & 18.0 & 62.0 & 8.5 & 14.0 & 16.5 \\
\hline 2002 & 62.8 & 28.6 & 60.5 & 75.3 & 56.0 & 11.0 & 17.9 & 19.2 & 60.2 & 9.3 & 13.3 & 17.4 \\
\hline 2003 & 65.0 & 28.4 & 64.2 & 75.6 & 69.3 & 11.8 & 20.4 & 19.5 & 61.6 & 10.4 & 15.3 & 17.5 \\
\hline 2004 & 60.1 & 28.1 & 60.5 & 75.0 & 54.5 & 9.3 & 16.8 & 17.7 & 60.5 & 8.0 & 13.4 & 14.8 \\
\hline 2005 & 59.9 & 27.7 & 63.7 & 74.9 & 53.3 & 11.3 & 17.6 & 16.8 & 60.4 & 8.0 & 11.8 & 14.6 \\
\hline 2006 & 65.3 & 27.1 & 61.5 & 74.2 & 48.9 & 11.4 & 18.7 & 17.3 & 52.9 & 9.8 & 15.0 & 14.3 \\
\hline 2007 & 62.8 & 26.0 & 61.9 & 72.6 & 56.6 & 9.4 & 15.3 & 16.8 & 69.1 & 7.6 & 10.8 & 14.1 \\
\hline 2008 & 65.1 & 25.2 & 58.3 & 72.1 & 49.4 & 9.3 & 15.4 & 16.1 & 51.3 & 7.0 & 10.5 & 11.8 \\
\hline \multirow[t]{3}{*}{ Average 2000-2008 } & 62.9 & 28.2 & 60.6 & 74.9 & 56.6 & 10.7 & 17.3 & 18.4 & 59.1 & 9.0 & 13.3 & 15.9 \\
\hline & \multicolumn{4}{|c|}{$\mathrm{SO}_{4}^{=}$} & \multicolumn{4}{|c|}{$\mathrm{NO}_{3}^{-}$} & \multicolumn{4}{|c|}{$\mathrm{NH}_{4}^{+}$} \\
\hline & $\rho$ & RMSE & $\mu_{\mathrm{obs}}$ & $\mu_{\text {sim }}$ & $\rho$ & RMSE & $\mu_{\mathrm{obs}}$ & $\mu_{\mathrm{sim}}$ & $\rho$ & RMSE & $\mu_{\mathrm{obs}}$ & $\mu_{\text {sim }}$ \\
\hline 2000 & 58.8 & 2.2 & 2.1 & 3.0 & 27.1 & 6.3 & 1.8 & 6.4 & 47.7 & 2.4 & 0.9 & 2.7 \\
\hline 2001 & 53.3 & 1.7 & 2.2 & 2.3 & 28.6 & 3.1 & 1.8 & 3.4 & 47.5 & 1.1 & 1.1 & 1.4 \\
\hline 2002 & 59.6 & 1.8 & 2.7 & 2.5 & 43.2 & 3.3 & 2.2 & 3.6 & 51.4 & 1.0 & 0.7 & 0.9 \\
\hline 2003 & 60.5 & 2.0 & 2.7 & 2.5 & 52.2 & 2.9 & 2.1 & 3.3 & 70.8 & 1.0 & 0.6 & 1.1 \\
\hline 2004 & 57.3 & 1.5 & 2.2 & 2.2 & 39.0 & 3.0 & 2.0 & 3.6 & 67.0 & 0.6 & 0.5 & 0.7 \\
\hline 2005 & 50.4 & 1.6 & 2.2 & 2.0 & 39.4 & 2.9 & 2.0 & 3.3 & 55.0 & 1.0 & 1.0 & 1.5 \\
\hline 2006 & 56.2 & 1.9 & 2.6 & 2.2 & 51.1 & 2.7 & 2.8 & 3.4 & 56.4 & 1.2 & 1.3 & 1.8 \\
\hline 2007 & 57.0 & 1.3 & 1.9 & 1.8 & 44.3 & 2.7 & 1.9 & 2.9 & 60.9 & 1.0 & 1.0 & 1.5 \\
\hline 2008 & 55.6 & 1.2 & 1.8 & 1.6 & 49.5 & 2.4 & 1.7 & 2.4 & 65.4 & 0.9 & 0.9 & 1.3 \\
\hline Average 2000-2008 & 56.5 & 1.7 & 2.3 & 2.2 & 41.6 & 3.3 & 2.0 & 3.6 & 58 & 1.1 & 0.9 & 1.4 \\
\hline
\end{tabular}

Table 2. Operational evaluation of the model using the criteria* of Russell and Dennis (2000) for $\mathrm{O}_{3}$ and of Boylan and Russell (2006) for $\mathrm{PM}$ and its components (expressed in \%).

\begin{tabular}{lrr|rr|rr|rr|r|r|r|r}
\hline & \multicolumn{2}{c}{$\mathrm{O}_{3}$} & \multicolumn{2}{c|}{$\mathrm{PM}_{10}$} & \multicolumn{2}{c|}{$\mathrm{PM}_{2.5}$} & \multicolumn{2}{c|}{$\mathrm{SO}_{4}^{=}$} & \multicolumn{2}{c|}{$\mathrm{NO}_{3}^{-}$} & \multicolumn{2}{c}{$\mathrm{NH}_{4}^{+}$} \\
\cline { 2 - 10 } Years & $\mathrm{MNB}$ & $\mathrm{MNE}$ & $\mathrm{MFB}$ & $\mathrm{MFE}$ & $\mathrm{MFB}$ & $\mathrm{MFE}$ & $\mathrm{MFB}$ & $\mathrm{MFE}$ & $\mathrm{MFB}$ & $\mathrm{MFE}$ & $\mathrm{MFB}$ & $\mathrm{MFE}$ \\
\hline 2000 & 17 & 23.8 & 47 & 54 & 55 & 62 & 28 & 48 & 89 & 103 & 84 & 89 \\
2001 & 9.8 & 19.5 & 10 & 41 & 25 & 42 & 0 & 45 & 3 & 93 & 1 & 55 \\
2002 & 7.6 & 19 & 17 & 44 & 36 & 50 & -6 & 44 & 25 & 84 & -7 & 55 \\
2003 & 3.4 & 19.5 & 7 & 38 & 25 & 45 & -9 & 43 & 28 & 76 & 43 & 59 \\
2004 & 5.2 & 17.6 & 13 & 39 & 22 & 42 & -3 & 40 & 29 & 83 & -5 & 52 \\
2005 & 1.2 & 18.1 & 8 & 45 & 33 & 48 & -7 & 45 & 6 & 86 & 7 & 57 \\
2006 & 2.4 & 17.3 & 3 & 40 & 10 & 40 & -12 & 44 & 5 & 71 & 23 & 50 \\
2007 & 0.9 & 17 & 21 & 45 & 37 & 53 & -3 & 41 & 8 & 78 & 24 & 47 \\
2008 & 0.2 & 14.1 & 11 & 40 & 25 & 47 & -7 & 39 & -8 & 75 & 17 & 40 \\
\hline Average & 5.3 & 18.4 & 15.2 & 42.9 & 29.8 & 47.4 & -2.1 & 43.2 & 20.5 & 83.2 & 20.8 & 56 \\
$2000-2008$ & & & & & & & & & & & \\
\hline
\end{tabular}

* The performance criteria are $|\mathrm{MNE}|<35 \%$ and $\mathrm{MNB}<15 \%$ for $\mathrm{O}_{3}$ modeling; a threshold of $80 \mu \mathrm{g} \mathrm{m}^{-3}$ was used here. The performance goal (resp. criterion) is met when $|\mathrm{MFB}|<30 \%(60 \%)$ and MFE $<50 \%$ (75\%) for PM modeling.

in Europe, where most $\mathrm{NH}_{4} \mathrm{NO}_{3}$ formation occurs during the cold season. An unbiased uncertainty of $15 \%$ has been reported for $\mathrm{NO}_{3}^{-}$measurements (Schaap et al., 2004). Also, the aerosol water content is not taken into account in modelto-data comparisons, but a small amount of water may remain in the PM mass measurements.

Table 1 shows the annual mean correlations between the simulated and the observed concentrations ( $\rho$ in $\%)$, the RMSE, and the mean concentrations of the observed data $\left(\mu_{\mathrm{obs}}\right)$ and of the simulated data $\left(\mu_{\text {sim }}\right)$, expressed in $\mu \mathrm{g} \mathrm{m}^{-3}$. On average, hourly $\mathrm{O}_{3}$ is overestimated by about $23 \%$, the correlation coefficient is $62.9 \%$, and the RMSE is $28.2 \mu \mathrm{g} \mathrm{m}^{-3}$ (the observed mean concentration is $60.6 \mu \mathrm{g} \mathrm{m}^{-3}$ ). The criteria of Russell and Dennis (2000) are met with an MNE of $18.4 \%$ and an MNB of $5.3 \%$ on 
average. Those criteria are met for all years except 2000, when MNB is $17 \%$ (instead of $\leq 15 \%$, see Table 2).

$\mathrm{PM}_{10}$ is estimated with a correlation coefficient of $56.6 \%$ and a RMSE of $10.7 \mu \mathrm{g} \mathrm{m}^{-3}$ on average (the observed mean concentration is $17.3 \mu \mathrm{g} \mathrm{m}^{-3}$ ). On average, MFB and MFE are $15.2 \%$ and $42.9 \%$, respectively, meeting the performance goal of Boylan and Russell (2006) (see Table 2). The performance goal is met every year except in 2000, when both MFB and MFE exceed the goals but meet the criteria. $\mathrm{PM}_{2.5}$ is overestimated by $20 \%$ on average with an RMSE of $9 \mu \mathrm{g} \mathrm{m}^{-3}$ (the observed mean concentration is $13.3 \mu \mathrm{g} \mathrm{m}^{-3}$ ) and a correlation coefficient of $59 \%$. On average, MFB $(29.8 \%)$ and MFE $(47.4 \%)$ also meet the performance goals. These performance goals are met for $5 \mathrm{yr}$ (2001, 2003, 2004, 2006, and 2008); for the other years, $\mathrm{PM}_{2.5}$ meets the performance criteria. $\mathrm{SO}_{4}^{=}$provides the best results: the correlation coefficient is $56.5 \%$ and the RMSE is $1.7 \mu \mathrm{g} \mathrm{m}^{-3}$ on average (the observed mean concentration is $2.3 \mu \mathrm{g} \mathrm{m}^{-3}$ ). Simulated concentrations are on average $4 \%$ lower than the observations. Both MFB $(-2.1 \%)$ and MFE $(43.2 \%)$ meet the model performance goals for every single year. Model performance is lower for $\mathrm{NO}_{3}^{-}$and $\mathrm{NH}_{4}^{+}$. Simulated concentrations are overestimated compared to the observed concentrations $\left(80 \%\right.$ for $\mathrm{NO}_{3}^{-}$ad $55 \%$ for $\mathrm{NH}_{4}^{+}$ on average). $\mathrm{NH}_{4}^{+}$has a better correlation coefficient and RMSE ( $58 \%$ and $1.1 \mu \mathrm{g} \mathrm{m}^{-3}$, the observed mean concentration is $0.9 \mu \mathrm{g} \mathrm{m}^{-3}$ ) than $\mathrm{NO}_{3}^{-}\left(42 \%\right.$ and $3.3 \mu \mathrm{g} \mathrm{m}^{-3}$, the observed mean concentration is $2 \mu \mathrm{g} \mathrm{m}^{-3}$ ) because a fraction of $\mathrm{NH}_{4}^{+}$is associated with $\mathrm{SO}_{4}^{=}$. $\mathrm{NO}_{3}^{-}$does not meet the performance criteria (MFB $=20.5 \%$ and $\mathrm{MFE}=83.2 \%$ on average), but $\mathrm{NH}_{4}^{+}$does $(\mathrm{MFB}=20.8 \%$ and $\mathrm{MFE}=56 \%)$. For $\mathrm{NO}_{3}^{-}$the performance criteria are met for $4 \mathrm{yr}(2003,2006,2007$, and 2008). For $\mathrm{NH}_{4}^{+}$the performance goals are met for the last $3 \mathrm{yr}$ (2006-2008), and the performance criteria for all years except 2000.

\subsection{Comparison with other model evaluations in the context of AQMEII}

Sartelet et al. (2012) summarized the results of an operational model performance evaluation conducted for the Polyphemus/Polair3D model and nine other models, applied in the context of the Air Quality Model Evaluation International Initiative (AQMEII, Solazzo et al., 2012). The mean of the statistics of the nine AQMEII models was computed, along with the minimum and maximum values, for $\mathrm{PM}_{10}$ and $\mathrm{PM}_{2.5}$. We compare here our model performance evaluation to that of the other AQMEII models. The AQMEII model evaluation was performed for a 2-month period (from 7 July to 31 August 2006). We thus computed the performance statistics for this study from 7 July to 31 August for each year and averaged the results over 2000-2008 for the comparison. It is interesting to ensure that our model performance did not degrade when simulating a longer time period. The observational data for the AQMEII model evaluation include stations from the AirBase and EMEP databases, while we only used the latter (AirBase does not provide data for the components of PM, while EMEP does). Table A1 summarizes the statistics obtained for $\mathrm{PM}_{10}$ and $\mathrm{PM}_{2.5}$.

Daily $\mathrm{PM}_{10}$ is slightly overestimated by Polair3D over 2000-2008 (15.9 $\mathrm{\mu g} \mathrm{m}^{-3}$ measured against $16.6 \mu \mathrm{g} \mathrm{m}^{-3}$ simulated), while the AQMEII model concentrations are on average $10 \mu \mathrm{g} \mathrm{m}^{-3}$ lower than the observations. The Polair3D average RMSE is about half the mean observed value, whereas the mean RMSE for the AQMEII models is commensurate with the observed value. The Polair3D average correlation coefficient is significantly higher than the best correlation coefficient for the AQMEII models. The MFE and MFB of Polair3D meet the performance goal criteria, while the AQMEII models do not. Solazzo et al. (2012) performed statistical analysis for $\mathrm{PM}_{10}$ for 10 model simulations in the context of AQMEII for the whole of year 2006. The RMSE ranges from 7.3 to $15.2 \mu \mathrm{g} \mathrm{m}^{-3}$ for the different models, which is consistent with the RMSE obtained here, which is $10.7 \mu \mathrm{g} \mathrm{m}^{-3}$ on average (see Table 1). The MFB for $\mathrm{PM}_{10}$ at rural stations ranges between $-70 \%$ and $+10 \%$ for the different AQMEII models, while in this work it is $15.2 \%$ on average. The MFE for the AQMEII models spreads from $25 \%$ to $75 \%$ for the different models, while it is $42.9 \%$ on average in this work.

Daily $\mathrm{PM}_{2.5}$ is overestimated compared to the observations $\left(11.5 \mu \mathrm{g} \mathrm{m}^{-3}\right.$ measured against $16 \mu \mathrm{g} \mathrm{m}^{-3}$ simulated on average). The AQMEII models show both under and overestimations $\left(13.3 \mu \mathrm{g} \mathrm{m}^{-3}\right.$ measured against a range of 5 to $21.4 \mu \mathrm{g} \mathrm{m}^{-3}$ simulated). The Polair3D average RMSE $\left(7.2 \mu \mathrm{g} \mathrm{m}^{-3}\right)$ is smaller than those of the AQMEII models, with similar mean observed values. The correlation coefficient is significantly better than those of the AQMEII models ( $68 \%$ against 3 to $21 \%$ ). Compared to the AQMEII models, the MFE and MFB of this simulation show better results and meet the model performance criteria of Boylan and Russell (2006), while the AQMEII models do not.

\subsection{Comparison with the performance evaluation of 1 yr simulations}

We also compared our model performance evaluation to that of four other chemical-transport models that have been used for $1 \mathrm{yr}$ simulations over Europe (see Appendix B): CHIMERE (Péré et al., 2010), CALIOPE-EU (Pay et al., 2010), WRF/Chem (Tuccella et al., 2012), and CMAQ (Appel et al., 2012), which respectively simulated 2003, 2004, 2007, and 2006. The Polair3D results are averaged over 2000-2008 for this comparison.

All models simulated different years, with different models and configuration. Péré et al. (2010) used respectively EMEP and MEGAN to generate anthropogenic and biogenic emissions. PM and trace gases $\left(\mathrm{CO}, \mathrm{VOC}, \mathrm{NO}, \mathrm{NO}_{2}\right)$ released by the important fires in 2003 were also taken into account. Pay et al. (2010) used the Advanced Research Weather Research and Forecasting (WRF-ARW) Model to 
provide meteorology, the EMEP database for anthropogenic emissions and the Dust Regional Atmospheric Model (BSCDREAM8b) to simulate the atmospheric cycle of mineral dust. Boundary conditions were provided by LMDz-INCA2. Appel et al. (2012) forced WRF with boundary conditions from the North American Model from the National Centers for Environmental Prediction to generate meteorological data. Anthropogenic and biogenic emissions were respectively provided by MEGAN and TNO (http://www.tno.nl/). Fire emissions from the Moderate Resolution Imaging Spectrora diameter (MODIS) fire radiative power product were taken into account. Boundary conditions were generated via the Global and Regional Earth System Monitoring using Satellite and in situ data (GEMS) product with the help of data provided by GEOS-Chem for chemical boundary conditions. The AERO05 aerosol module and the CB05 mechanism were used. Tuccella et al. (2012) forced WRF/Chem with meteorological initial and boundary conditions provided by ECMWF. The chemical boundary conditions of trace gases are based upon the results from the NOAA Aeronomy Lab Regional Oxidant Model (NALROM). The gasphase chemistry model used is the Regional Acid Deposition Model, version 2 (RADM2), and the aerosol module includes the Modal Aerosol Dynamics Model for Europe (MADE) for the inorganic fraction, and the Secondary Organic Aerosol Model (SORGAM) for the carbonaceous secondary fraction.

The performance of $\mathrm{PM}_{2.5}$ obtained is comparable to that of the other models; CHIMERE shows better correlations but similar normalized mean bias (NMB), the correlation obtained with Polair3D is better than those of CALIOPE-EU and WRF/Chem, but WRF/Chem shows lower MNB and $\mathrm{MNE}$ than Polair3D. For $\mathrm{SO}_{4}^{=}$, Polair3D and CHIMERE show good agreement with the observations on average (within $0.1 \mu \mathrm{g} \mathrm{m}^{-3}$ ), whereas WRF/Chem underestimates significantly. All models overestimate $\mathrm{NO}_{3}^{-}$, but the bias is lower for CHIMERE than for WRF/Chem and Polair3D. Performance results for $\mathrm{NH}_{4}^{+}$are similar for Polair3D, CHIMERE, and WRF/Chem.

\subsection{Discussion}

The operational model evaluation showed that $\mathrm{NO}_{3}^{-}$and $\mathrm{NH}_{4}^{+}$are overestimated. This overestimation results from a combination of various factors. First, artifacts in the measurements methods, due to the volatilization of $\mathrm{NH}_{4} \mathrm{NO}_{3}$ from filters, can contribute to the model overestimation, although an evaluation of nitrate measurement methods in Europe did not show any significant bias (Schaap et al., 2004). In addition, the overestimation of nitrate could be due to the slight underestimation of sulfate by the model $\left(2.2 \mu \mathrm{g} \mathrm{m}^{-3}\right.$ simulated against $2.3 \mu \mathrm{g} \mathrm{m}^{-3}$ in the measurements). Thus, not enough ammonia is consumed by $\mathrm{SO}_{4}^{=}$, favoring the formation of additional $\mathrm{NH}_{4} \mathrm{NO}_{3}$. Also, there is still a significant uncertainty about ammonia emissions, including their magnitude and temporal variability. Finally, taking the mean over 5 yr to generate pseudo-climatological boundary conditions for aerosols and gases is also a source of uncertainties.

The overestimation of $\mathrm{PM}_{10}$ is slight $\left(18.4 \mu \mathrm{g} \mathrm{m}^{-3}\right.$ simu-

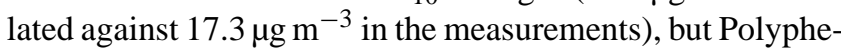
mus tends to simulate greater $\mathrm{PM}_{10}$ concentrations than other models over Europe (Sartelet et al., 2012). The comprehensive treatment of organic aerosols in Polyphemus, which leads to reasonable agreement with observations of carbonaceous aerosols (Couvidat et al., 2012), can explain in part this slight overestimation because the $\mathrm{NO}_{3}^{-}$overestimation is not compensated by an organic underestimation as it was the case in some earlier modeling studies). The overestimation of daily $\mathrm{PM}_{2.5}$ can be explained by the overestimation of $\mathrm{NO}_{3}^{-}$, which is a greater fraction of $\mathrm{PM}_{2.5}$ than of $\mathrm{PM}_{10}$.

The evolution of model performance over the years shows a clear improvement for $\mathrm{O}_{3}, \mathrm{NH}_{4}^{+}$, and $\mathrm{NO}_{3}^{-}$from 2000 to 2008. This improvement could be due to improvement in the measurements, the emission inventory, the meteorology (better spatial resolution for the more recent years), the boundary conditions (year-specific values starting in 2004) or a combination thereof. It is not possible at this point to identify conclusively the driving source of this evolution; nevertheless, model performance is satisfactory on average for $\mathrm{PM}_{2.5}$ and its components and is similar to that of other models.

\section{Dynamic evaluation}

\subsection{Data sets and method}

A dynamic evaluation of an air quality model with respect to meteorology requires a long period to provide sufficient meteorological variability to evaluate the response of $\mathrm{PM}_{2.5}$ concentrations to variations in meteorology. The long duration used here (2000-2008) allows one to perform such a dynamic evaluation and test the ability of the model to correctly reproduce the variability of the concentrations of $\mathrm{PM}_{2.5}$ and of its components in response to meteorology (e.g., temperature, wind speed, precipitation). Available $\mathrm{PM}_{2.5}$ EMEP measurements provide 23 stations, which give daily observations for at least a year, but only 5 stations have EMEP joint observations for $\mathrm{PM}_{2.5}, \mathrm{SO}_{4}^{=}, \mathrm{NO}_{3}^{-}$and $\mathrm{NH}_{4}^{+}$for the same period and for which a reasonable percentage of the data is available. The station locations are shown in Fig. 1. The five stations, which include joint observations of $\mathrm{PM}_{2.5}$ and inorganic components, are AT02 in Austria (2003-2008), DE02 and DE03 in Germany (2006-2008), IT01 in Italy (20072008), and NO01 in Norway (2002-2008). NO01 does not provide daily $\mathrm{PM}_{2.5}$ observations (only 2 to 3 times per week); however, it provides $\mathrm{SO}_{4}^{=}, \mathrm{NO}_{3}^{-}$, and $\mathrm{NH}_{4}^{+}$observations on a daily basis. The AT02 station is located near Lake Neusiedl in Austria at $117 \mathrm{~m}$ above mean sea level (a.m.s.l.). The closest city is Illmitz (2416 inhabitants). The DE02 station is located at 74 a.m.s.l., in a forest with agriculture and meadows at a distance of $1 \mathrm{~km}$ and is surrounded by small 
stationary $\mathrm{SO}_{2}$ and $\mathrm{NO}_{\mathrm{x}}$ sources at distances greater than $1 \mathrm{~km}$. The two largest and closest cities are Ützen (35600 inhabitants, $22 \mathrm{~km}$ from the station) and Salzwedel (21 000 inhabitants, $27 \mathrm{~km}$ from the station). Local emissions from cars should not affect the measurements as there are approximatively 3 cars per day within $3 \mathrm{~km}$ around the station. The DE03 station is situated on a mountain in the Black Forest, at 1205 a.m.s.l. and surrounded by forests and meadows, where there is minor agricultural activity for some parts of the year. Freiburg (206000 inhabitants) is $12 \mathrm{~km}$ from the station and there are approximatively 5 vehicles per day within $10 \mathrm{~km}$ around the station. The high altitude of the DE03 station compared to the other sites should not impact the results of the dynamic evaluation as both measured and simulated concentrations are surface data (Polair3D uses terrain-following coordinates). The IT01 station is located at 48 a.m.s.l. and is $30 \mathrm{~km}$ from Rome. The station has the particularity to be inside the Research Area of the National Council of Italy; therefore, the site could be influenced by the vehicles of the research personel. There is no relevant industry near the area, but there is a highway situated $1.7 \mathrm{~km}$ from the station. The proximity to a large city and a highway could lead to greater concentrations of primary PM, as well as some lesser influence on concentrations of secondary $\mathrm{PM}$ (i.e., $\mathrm{SO}_{4}^{=}, \mathrm{NO}_{3}^{-}$, and $\mathrm{NH}_{4}^{+}$), but those should be taken into account by the model. The NO01 station is surrounded mainly by forest, meadows, freshwater lakes, and low-intensity agricultural areas; it is located at 190 a.m.s.l. There are some local known emissions, which have minor or negligible influence on the air quality of the site. Some local agricultural activities occasionally yield elevated ammonia concentrations.

For the observation data set, we used the EMEP observations for the pollutants, the ENSEMBLES ${ }^{2}$ observations for temperature and precipitation (horizontal resolution of $0.5^{\circ} \times 0.5^{\circ}$ ), and the ERA Interim ${ }^{3}$ data for wind speed (horizontal resolution of $1.5^{\circ} \times 1.5^{\circ}$ ). The Polyphemus/Polair3D simulation results were used for both $\mathrm{PM}_{2.5}$ concentrations and meteorology of the simulation data set.

We computed for each station the correlations between the meteorology on a given day and the PM daily concentrations ranging from 0 to 10 days after for both observed and simulated values. We refer to the differences between those days as the lag (i.e., ranging from 0 to +10 ). For example, at lag $=0$, the computed correlation corresponds to a day-today correlation. For lag $=+10$, the correlation is computed with the meteorology on a given day and the PM concentrations 10 days later. Therefore, it may reflect the impact of meteorology on the PM concentrations 10 days later. We assume in our analysis that the association between a meteorological variable and a PM concentration reflects the impact of meteorology on PM levels. If the correlation is highest when the lag is 0 , then the correlation represents an associ-

\footnotetext{
${ }^{2}$ http://eca.knmi.nl/download/ensembles/ensembles.php

${ }^{3}$ http://www.ecmwf.int/research/era/do/get/era-interim
}

ation between a meteorological variable and a PM concentration for the same day. It is the case at several stations (see station specific discussions below) for wind speed and precipitation. A negative correlation between precipitation and PM concentrations can be interpreted as wet scavenging of PM: greater precipitation leads to lower PM concentrations. Similarly, a negative correlation between wind speed and PM concentrations can be interpreted as greater dispersion of primary PM emissions (and/or emissions of precursors): greater wind speed leads to lower PM concentrations. Because the $\mathrm{PM}$ concentration is a $24 \mathrm{~h}$ average value, a meteorological event (e.g., precipitation) may impact the PM concentrations more the following day than the same day if it occurs near the end of that same day at a large spatial scale. The concentrations measured the following day will thus represent an air mass that has been affected by the meteorological event. If the spatial scale of the meteorological event is significant and/or if there is stagnation, the "memory" of the meteorological event may last for several days and the correlation may remain significant for a few days. The correlation between PM and wind speed/precipitation reaches its maximum value (absolute value) for a lag equal to 0 or +1 and then tends towards 0 for the lag equal to 10 . This suggests that wind speed/precipitation have little impact on PM beyond 4 days. The correlations between temperature and pollutants are nearly constant for a given station and a given pollutant. This suggests that temperature impacts PM over a much longer period compared to wind speed and precipitation. This behavior reflects the fact that temperature differences are significant among seasons and synoptic systems but show little day-to-day variation except for frontal passages.

We divide our dynamic evaluation into two parts. We first focus on the 23 stations that provide $\mathrm{PM}_{2.5}$ measurements in Sect. 4.2. We conduct a greater in-depth analysis on the 5 stations that provide $\mathrm{PM}_{2.5}, \mathrm{SO}_{4}^{=}, \mathrm{NO}_{3}^{-}$, and $\mathrm{NH}_{4}^{+}$in Sect. 4.3.

\subsection{Dynamic evaluation of $\mathrm{PM}_{2.5}$ at EMEP stations}

The correlations computed above may be represented with curves depicting the evolution of the correlations as a function of the day lag (one graph per station). The large number of stations providing $\mathrm{PM}_{2.5}$ measurements (23) prevents us from using this approach, which is used for a detailed analysis at the five stations that include $\mathrm{PM}_{2.5}$ components. Instead, we choose to perform here a linear regression analysis to describe the evolution of these correlations as a function of the day lag, in both simulation and observation, allowing us a more compact presentation of these results (see Table 3 ). In this evaluation, the day lag ranges from 0 to 2 for two reasons. First, the general evolution of the correlation as a function of the day lag does not show linear relationships over 10 days but does over the first 3 days. Moreover, the best correlation coefficients for precipitation and wind speed suggest that they have little impact on PM beyond 4 days. If both the regression coefficients and the best correlations are 
Table 3. Dynamic evaluation for $\mathrm{PM}_{2.5}$ (without speciation): linear regression analysis of the correlation coefficients between the $\mathrm{PM}_{2.5}$ and temperature $\left(\mathrm{T}^{\circ} \mathrm{C}\right.$ ), precipitation (PR), and wind speed (WS) as a function of the day lag (ranging from 0 to 2 ) for the observed (obs) and simulated (sim) concentrations. reg is the regression coefficient obtained from the regression analysis and $r$ is the best correlation coefficient.

\begin{tabular}{|c|c|c|c|c|c|c|c|c|c|c|c|c|}
\hline \multirow{3}{*}{ Station } & \multicolumn{4}{|c|}{ Correlation of $\mathrm{PM}_{2.5}$ vs. $\mathrm{T}^{\circ} \mathrm{C}$} & \multicolumn{4}{|c|}{ Correlation of $\mathrm{PM}_{2.5}$ vs. PR } & \multicolumn{4}{|c|}{ Correlation of $\mathrm{PM}_{2.5}$ vs. WS } \\
\hline & \multicolumn{2}{|c|}{ obs } & \multicolumn{2}{|c|}{$\operatorname{sim}$} & \multicolumn{2}{|c|}{ obs } & \multicolumn{2}{|c|}{$\operatorname{sim}$} & \multicolumn{2}{|c|}{ obs } & \multicolumn{2}{|c|}{$\operatorname{sim}$} \\
\hline & reg & $r$ & reg & $r$ & reg & $r$ & reg & $r$ & reg & $r$ & reg & $r$ \\
\hline AT02 & -0.02 & -0.46 & -0.01 & -0.43 & -0.02 & -0.21 & -0.01 & -0.19 & 0.03 & -0.11 & 0.1 & -0.46 \\
\hline AT48 & -0.03 & -0.09 & -0.03 & 0.14 & 0.02 & -0.22 & 0.02 & -0.19 & 0.02 & -0.16 & 0.09 & -0.45 \\
\hline $\mathrm{CH} 02$ & -0.03 & -0.41 & -0.02 & 0.11 & -0.03 & -0.34 & 0.05 & -0.3 & 0.02 & -0.22 & 0.05 & -0.41 \\
\hline $\mathrm{CH} 04$ & -0.03 & 0.18 & -0.02 & 0.11 & 0 & -0.37 & 0.06 & -0.32 & 0.02 & -0.32 & 0.06 & -0.38 \\
\hline DE02 & -0.03 & -0.3 & -0.02 & -0.11 & -0.04 & -0.23 & -0.02 & -0.18 & 0.02 & -0.25 & 0.05 & -0.41 \\
\hline DE03 & -0.03 & 0.32 & -0.03 & 0.21 & -0.01 & -0.27 & 0.06 & -0.35 & 0.02 & -0.3 & 0.06 & -0.53 \\
\hline DE04 & -0.03 & -0.12 & -0.04 & 0.18 & -0.01 & -0.39 & 0.06 & -0.3 & 0.08 & -0.38 & 0.08 & -0.54 \\
\hline DE44 & -0.03 & -0.31 & -0.02 & -0.14 & -0.03 & -0.25 & 0 & -0.22 & 0.05 & -0.31 & 0.06 & -0.47 \\
\hline ES07 & -0.04 & 0.48 & -0.01 & 0.26 & -0.02 & -0.19 & 0.08 & -0.32 & 0.03 & -0.18 & 0.05 & -0.31 \\
\hline ES08 & -0.05 & 0.23 & -0.02 & 0.1 & 0.01 & -0.27 & 0.04 & -0.22 & 0.07 & -0.31 & 0.05 & -0.24 \\
\hline ES09 & -0.03 & 0.55 & -0.03 & 0.06 & 0 & -0.16 & 0.03 & -0.2 & 0.03 & -0.39 & 0.06 & -0.53 \\
\hline ES10 & -0.02 & 0.12 & -0.03 & 0.16 & -0.03 & -0.12 & 0.07 & -0.28 & -0.03 & -0.24 & 0.06 & -0.5 \\
\hline ES11 & -0.03 & 0.44 & -0.01 & -0.05 & 0 & -0.23 & 0.05 & -0.22 & 0.03 & -0.35 & 0.08 & -0.48 \\
\hline ES12 & -0.03 & 0.38 & -0.01 & 0.2 & 0.03 & -0.17 & 0.05 & -0.2 & 0.06 & -0.41 & 0.07 & -0.57 \\
\hline ES13 & -0.04 & 0.37 & -0.02 & -0.05 & 0.01 & -0.21 & 0.05 & -0.27 & 0.08 & -0.37 & 0.08 & -0.54 \\
\hline ES14 & -0.02 & -0.05 & -0.02 & -0.1 & -0.01 & -0.14 & 0 & -0.09 & 0.11 & -0.42 & 0.1 & -0.53 \\
\hline ES15 & -0.03 & 0.51 & -0.02 & -0.15 & -0.01 & -0.16 & 0.05 & -0.27 & -0.01 & -0.25 & 0.06 & -0.48 \\
\hline GB36 & -0.02 & -0.13 & -0.02 & -0.1 & -0.04 & -0.2 & -0.01 & -0.18 & 0.04 & -0.31 & 0.06 & -0.4 \\
\hline GB48 & -0.01 & -0.19 & 0.04 & -0.27 & -0.02 & -0.17 & 0.03 & -0.16 & -0.01 & -0.19 & 0.03 & -0.19 \\
\hline IT01 & -0.03 & -0.18 & -0.02 & -0.18 & 0.02 & -0.27 & 0.04 & -0.24 & 0.08 & -0.24 & 0.12 & -0.53 \\
\hline IT04 & 0 & -0.55 & -0.01 & 0.12 & -0.01 & -0.22 & -0.04 & -0.29 & 0.03 & -0.23 & 0.09 & -0.27 \\
\hline NO01 & -0.03 & 0.14 & -0.01 & -0.16 & -0.04 & -0.17 & -0.06 & 0.08 & -0.01 & -0.2 & 0.03 & -0.1 \\
\hline SI08 & -0.02 & -0.09 & -0.02 & -0.11 & -0.07 & -0.29 & 0.1 & -0.32 & 0.02 & 0.09 & 0.07 & -0.26 \\
\hline
\end{tabular}

close in the observations and in the simulation for a given station and a given meteorological variable, then we assume that the evolution of the relationship between this meteorological variable and the $\mathrm{PM}_{2.5}$ concentrations as a function of the day lag is well reproduced by the model.

The stations that give the best results are AT02, $\mathrm{CH04}$, ES08, ES12, ES14, GB36, and IT01 (values of the regression coefficients and correlations given in this section are the arithmetic means of the observational and simulation data, unless noted otherwise; the individual values are given in Table 3). At $\mathrm{CH} 04$ the regression coefficients for temperature are -0.02 and -0.03 , respectively, in simulation and observation, and the maximum correlation $(0.18$ in the observation, 0.11 in the simulation) occurs at $1 a g=0$ in both cases. The regression coefficients for both simulation and observation are close to 0.04 for wind speed and precipitation, and with a maximum correlation of around -0.35 at lag $=1$. At ES08 the regression coefficients for temperature, precipitation, and wind speed are close to $-0.03,0.02$, and 0.06 , respectively, and the maximum correlations for temperature, precipitation, and wind speed are close to 0.15, 0.25, and -0.27 , respectively, in both simulation and observation. At GB36 the regression coefficients for temperature, precipitation, and wind speed are respectively close to $-0.02,-0.02$, and 0.05 for both simulation and observation. The maximum correlations are also close for each variable in both simula- tion and observation. AT02, ES12, ES14, and IT01 present similar results.

The evolution of the correlation between the $\mathrm{PM}_{2.5}$ concentrations and the precipitation is typically what is best reproduced by the model at most of the stations (AT02, AT48, DE02, DE44, ES08, ES09, ES11, ES12, ES13, ES14, GB36, GB48, IT01, and IT04). The correlation curves at most of these stations are nearly identical, which can be seen on the values of the regression coefficients, ranging from -0.04 to 0.05 among the stations, with close values between observation and simulation (with a difference lower than 0.03 except at ES11 and ES13). The lag for which the best correlation is observed is lag $=1$ for most of the cases and for both simulation and observation. The values of the best correlation coefficients are also close in both simulation and observation within $30 \%$ at 17 out of 23 stations, for example, at CH02 (around -0.33), DE44 (around -0.23), ES11 (around -0.23 ), and IT01 (around -0.25 ). The differences between the values of the regression coefficients in simulated and observed data mainly come from a difference between the values of the correlation for lag $=0$ and 1 (at ES10 for example). At other stations the profile is the same between observation and simulation, but with a slight constant difference (at NO01 for example).

The evolution of the correlation between temperature and $\mathrm{PM}_{2.5}$ concentrations is not as well reproduced by the model. 
The results are best at the AT02, ES10, ES14, GB36, IT01, and SI08 stations, where the curves are nearly identical. At these stations the regression coefficients are either -0.02 or -0.03 and are nearly the same in simulation and observation. The best observed correlation is around -0.45 at AT02, +0.15 at $\mathrm{ES} 10,-0.07$ at $\mathrm{ES} 14,-0.12$ at GB36, -0.18 at IT01, and around -0.10 at SI08 for both simulation and observation. Other stations present similar regressions, but with a constant difference between the values of the correlation between the observed and the simulated data (AT48, DE02, DE03, DE44, ES07, ES08, ES09, ES12, and GB48). For some other stations, the correlation is not well reproduced by the model (CH02, DE04, ES11, ES13, ES15, IT04, and NO01). For these stations the best correlation is of opposite sign in the simulation compared to the observation.

The evolution of the correlation between wind speed and $\mathrm{PM}_{2.5}$ concentrations is also difficult to correctly reproduce, mainly because of the resolution of the ERA Interim data $(150 \mathrm{~km}$ instead of $50 \mathrm{~km}$ for Polyphemus and the ENSEMBLES data). The GB36 station provides the best results with the two correlation curves nearly identical (regression coefficients of 0.05 , and best correlation of around -0.35 observed at lag $=0$ in both simulation and observation). However, at most of the stations, the profile of the evolution is correctly reproduced by the model, but with a tendency of the model to overestimate the values of the correlations (at 21 out of 23 stations).

The ability of the model to predict changes in $\mathrm{PM}_{2.5}$ in response to changes in meteorology may be summarized as follows. Correlations with precipitation are always negative as expected as it removes PM from the atmosphere. The best correlation is observed for lag $=0$ or $\operatorname{lag}=1$, and the regression coefficient is positive for both observation and simulation. We conclude that the model reproduces the effect of precipitation on PM correctly. Correlations with wind speed have the same profile as for precipitation, suggesting that greater wind speed disperses the polluted air mass more efficiently. This effect is reproduced by the model; however, it tends to be overestimated. Correlations with temperature are more difficult to reproduce. The best correlation coefficient can be either positive or negative, depending on the stations. The regression coefficients are almost always 0 , suggesting that temperature impacts $\mathrm{PM}_{2.5}$ in the same way for several consecutive days. The difficulty to correctly reproduce these correlations is mainly due to the fact that temperature has different effects on the $\mathrm{PM}_{2.5}$ components (i.e., $\mathrm{SO}_{4}^{=}$, $\mathrm{NO}_{3}^{-}, \mathrm{NH}_{4}^{+}$, organics, ...), unlike precipitation and wind speed, which impact $\mathrm{PM}_{2.5}$ components in the same way. Exceptions are sea salt and mineral dust, for which emissions increase with wind speed; however, these components are mostly present in coarse PM. A more detailed analysis could not be performed here because most of these stations do not provide daily observations of $\mathrm{SO}_{4}^{=}, \mathrm{NO}_{3}^{-}$, and $\mathrm{NH}_{4}^{+}$.
Such an analysis is conducted below for the 5 stations that have joint observations for $\mathrm{PM}_{2.5}, \mathrm{SO}_{4}^{=}, \mathrm{NO}_{3}^{-}$, and $\mathrm{NH}_{4}^{+}$.

\subsection{Dynamic evaluation of $\mathrm{PM}_{2.5}$ and its main components at EMEP stations}

We analyze here the ability of the model to reproduce the effects of meteorology on $\mathrm{PM}_{2.5}$ inorganic components, i.e., $\mathrm{SO}_{4}^{=}, \mathrm{NO}_{3}^{-}$, and $\mathrm{NH}_{4}^{+}$, by comparing the correlations between concentrations of $\mathrm{PM}_{2.5}$ components and meteorological variables obtained in the observations and simulation.

Figure 4 presents these correlations for the AT02 station in Austria. Figure 4a shows that the model represents well the variation of $\mathrm{PM}_{2.5}$ as a function of changes in meteorology, particularly for temperature and precipitation. Correlations for temperature and precipitation versus $\mathrm{PM}_{2.5}$ are nearly identical for both simulated and observed data, while correlations for wind speed versus $\mathrm{PM}_{2.5}$ have the same profile but not the same intensity $(-0.38$ for simulated data against -0.11 for observational data with a lag taken at 0 ). The evolution of $\mathrm{SO}_{4}^{=}, \mathrm{NO}_{3}^{-}$, and $\mathrm{NH}_{4}^{+}$concentrations as a function of changes in precipitation and temperature are well represented. The evolution of $\mathrm{SO}_{4}^{=}$as a function of changes in temperature is well represented by the model, while the model gives a slightly larger correlation in absolute values for $\mathrm{NO}_{3}^{-}(\sim-0.4$ vs. $\sim-0.3)$ and $\mathrm{NH}_{4}^{+}(\sim-0.3$ vs. $\sim-0.25)$. For wind speed, the simulated data give a larger correlation in absolute value than the observations for all three species, which is consistent with the $\mathrm{PM}_{2.5}$ results. Simulation data show that the negative correlation between temperature and $\mathrm{PM}_{2.5}$ is driven by all the $\mathrm{PM}$ components (around -0.15 for $\mathrm{SO}_{4}^{=},-0.2$ for sea salt, -0.4 for $\mathrm{NO}_{3}^{-}, \mathrm{NH}_{4}^{+}$, and organic matter, and -0.6 for black carbon), except mineral dust (near 0). Lower temperatures in winter are associated with greater emissions of $\mathrm{NO}_{\mathrm{x}}, \mathrm{SO}_{2}$, elemental carbon and primary organic carbon (residential heating and fossil-fuelfired power plants), which may explain the greater concentrations of $\mathrm{SO}_{4}^{=}$, carbonaceous $\mathrm{PM}$, and nitric acid. Lower temperatures also favor the formation of semivolatile $\mathrm{NH}_{4} \mathrm{NO}_{3}$. Higher temperatures favor emissions of biogenic precursors of secondary organic aerosol (SOA); however, the results suggest that the variability of primary organic aerosol (POA) dominates over that of SOA. Profiles for wind and precipitation are identical for all species with some variation on the intensity of the correlation for a lag taken at 0 (the correlation then increases from lag $=0$ to lag $=+10$ ), except for sea salt, for which the maximum value of the correlation is positive. Over the sea, increases in wind speed are often linked to increases in precipitation rate and lead to the emissions and subsequent transport of suspended sea salt particles. The negative correlation of sea salt with temperature may result from the association of low temperature with high wind speeds (winter storms).

Figure 5 presents correlations for the DE02 station in Germany. The evolution of $\mathrm{SO}_{4}^{=}$as a function of changes in 


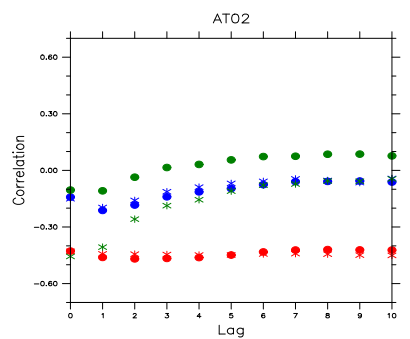

(a) $\mathrm{PM}_{2.5}$

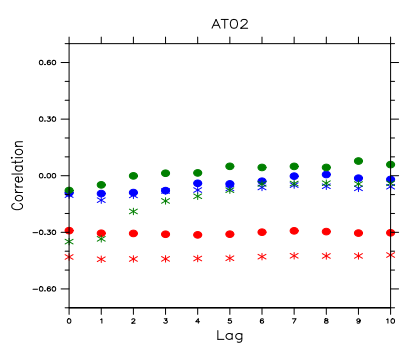

(c) Nitrate

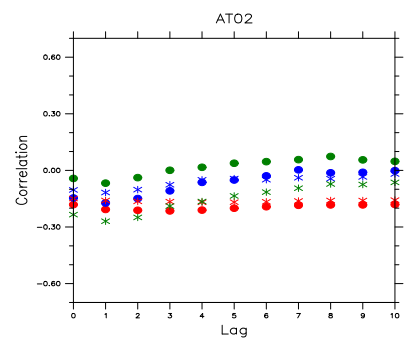

(b) Sulfate

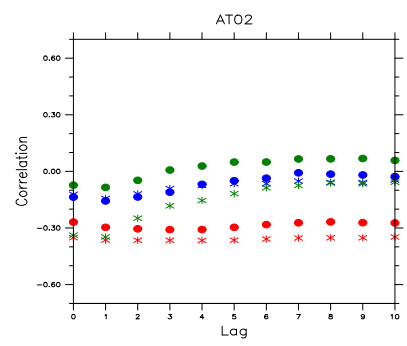

(d) Ammonium
Fig. 4. Correlations between meteorology (temperature in red, precipitation in blue, wind speed in green) on a given day and pollutant concentrations ( $\mathrm{PM}_{2.5}$, sulfate, nitrate, and ammonium), ranging up to 10 days after at AT02 (2003-2008). Simulated data are represented with a star, while observational data are represented with a dot.

meteorology is well represented. As for AT02, the model reproduces well the evolution of PM concentrations as a function of changes in precipitation. Similarly, the observations show correlations between PM and wind speed that have similar profiles but are greater than those of the simulation. The evolution of $\mathrm{PM}_{2.5}$ as a function of changes in temperature is not as well represented by the model $(-0.10$ for the simulation against -0.25 for the observations) as for AT02 because of the difficulty of the model to correctly represent changes in $\mathrm{NO}_{3}^{-}$and $\mathrm{NH}_{4}^{+}$(correlations of -0.30 to -0.40 for the observations and of -0.05 to -0.10 for the model). $\mathrm{NO}_{3}^{-}$modeled concentrations are similar in winter $\left(3.7 \mu \mathrm{g} \mathrm{m}^{-3}\right)$ and in summer $\left(3 \mu \mathrm{g} \mathrm{m}^{-3}\right)$, whereas they are significantly different in the observations $\left(4.7 \mu \mathrm{g} \mathrm{m}^{-3}\right.$ in winter against $1.1 \mu \mathrm{g} \mathrm{m}^{-3}$ in summer) (see Table 4). The differences between modeled and observed concentrations could be due to artifacts in the $\mathrm{NO}_{3}^{-}$measurements in summer due to $\mathrm{NH}_{4} \mathrm{NO}_{3}$ volatility (Hering and Cass, 1999), which would then explain the differences between the modeled and simulated correlations, but it could also result from uncertainties in the simulation, which, as shown in Sect. 3, overestimate $\mathrm{NO}_{3}^{-}$. Simulation data show that the negative correlation between temperature and $\mathrm{PM}_{2.5}$ is driven by all the $\mathrm{PM}$ components (around -0.10 for $\mathrm{SO}_{4}^{=}, \mathrm{NO}_{3}^{-}, \mathrm{NH}_{4}^{+}$, and organic matter, -0.20 for sea salt, and -0.30 for black carbon), except mineral dust (around 0.15). As for AT02, profiles for wind speed and precipitation are identical for all species, except for sea salt.

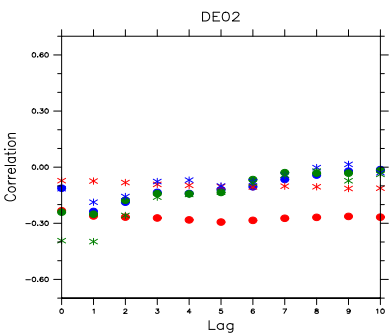

(a) $\mathrm{PM}_{2.5}$

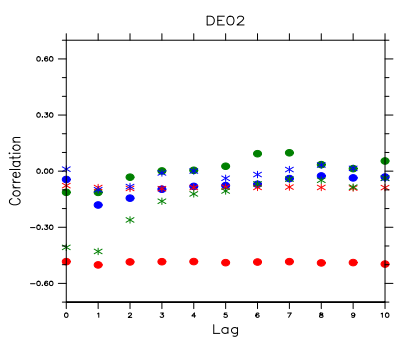

(c) Nitrate

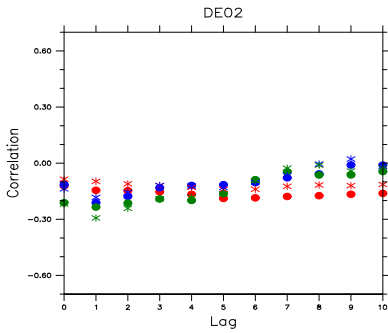

(b) Sulfate

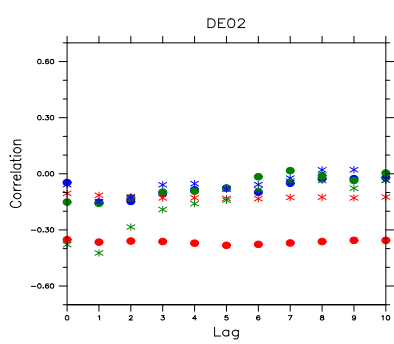

(d) Ammonium
Fig. 5. Correlations between meteorology (temperature in red, precipitation in blue, wind speed in green) on a given day and pollutant concentrations ( $\mathrm{PM}_{2.5}$, sulfate, nitrate, and ammonium), ranging up to 10 days after at DE02 (2006-2008). Simulated data are represented with a star, while observational data are represented with a dot.

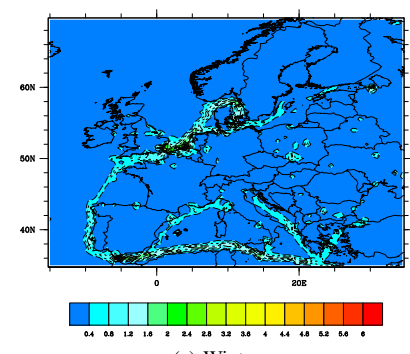

(a) Winter

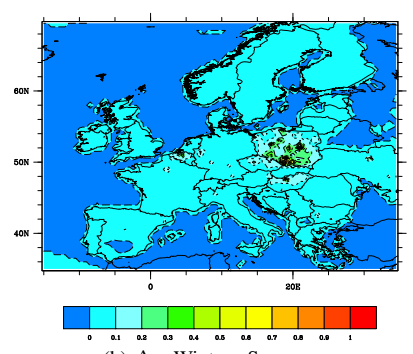

(b) $\Delta=$ Winter - Summer
Fig. 6. Average sulfur dioxide emissions over Europe in winter, and difference $(\Delta)$ between winter and summer, expressed in $\mu \mathrm{g} \mathrm{m}^{-2}$ $\mathrm{h}^{-1}$.

The AT02 and DE02 stations show negative correlations between temperature and $\mathrm{SO}_{4}^{=} \cdot \mathrm{SO}_{4}^{=}$concentrations depend on $\mathrm{SO}_{2}$ emissions (shown in Fig. 6), which may vary by season, and on the conversion rate of $\mathrm{SO}_{2}$ to $\mathrm{SO}_{4}^{=}$, which is greater in summer when oxidant concentrations are greater and kinetics faster. $\mathrm{SO}_{2}$ emissions are greater over Poland in winter than in summer (i.e., when temperatures are low, which suggests that $\mathrm{SO}_{4}^{=}$concentrations at these two stations are governed more by $\mathrm{SO}_{2}$ emissions than by the kinetics of $\mathrm{SO}_{2}$ to $\mathrm{SO}_{4}^{=}$conversion). A first reason comforting this hypothesis is that the $\mathrm{SO}_{2}$ emission impact is more visible at the AT02 station (correlation of around -0.3), which is closer to the $\mathrm{SO}_{2}$ emission sources, than at the DE02 station (correlation of around -0.15 ). Furthermore, daily mean 
Table 4. Mean simulated (sim) and observed (obs) concentrations of sulfate, nitrate, and ammonium in winter (December-January-February, DJF) and in summer (June-July-August, JJA) at the five stations, expressed in $\mu g \mathrm{~m}^{-3}$.

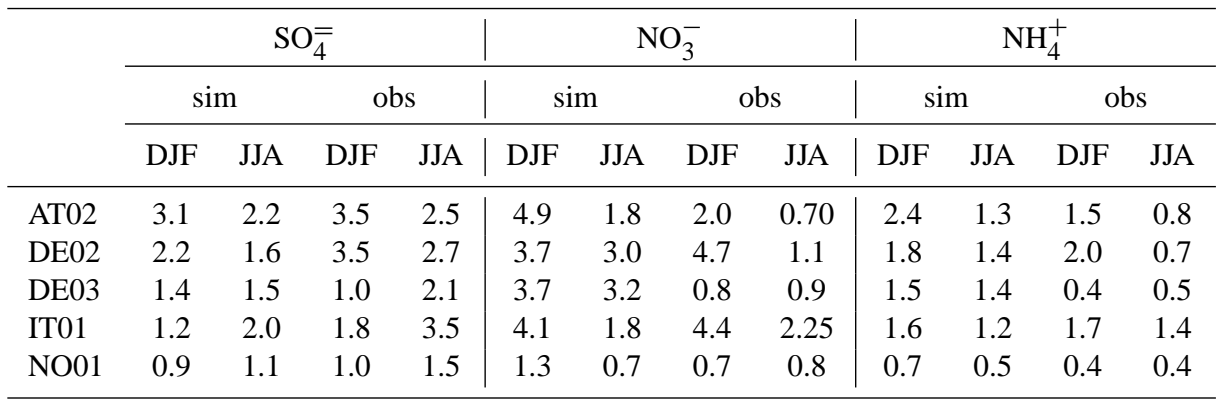

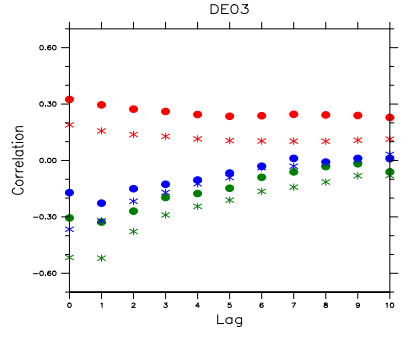

(a) $\mathrm{PM}_{2.5}$

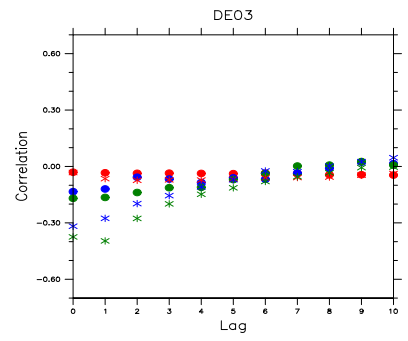

(c) Nitrate

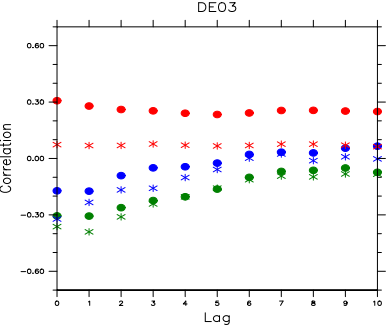

(b) Sulfate

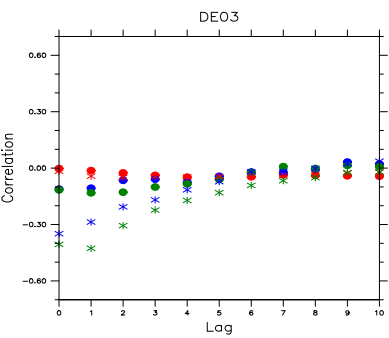

(d) Ammonium
Fig. 7. Correlations between meteorology (temperature in red, precipitation in blue, wind speed in green) on a given day and pollutant concentrations ( $\mathrm{PM}_{2.5}$, sulfate, nitrate, and ammonium), ranging up to 10 days after at DE03 (2006-2008). Simulated data are represented with a star, while observational data are represented with a dot.

concentrations of $\mathrm{SO}_{4}^{=}$are higher at these stations in winter $\left(3.1 \mu \mathrm{g} \mathrm{m}^{-3}\right.$ at AT02 and $2.2 \mu \mathrm{g} \mathrm{m}^{-3}$ at DE02) than in summer $\left(2.2 \mu \mathrm{g} \mathrm{m}^{-3}\right.$ at AT02 and $1.6 \mu \mathrm{g} \mathrm{m}^{-3}$ at DE02; see Table 4); these seasonal differences demonstrate that $\mathrm{SO}_{4}^{=}$ concentrations at AT02 and DE02 are more affected by $\mathrm{SO}_{2}$ emissions than by the kinetics of $\mathrm{SO}_{4}^{=}$formation.

Figure 7 shows the results for the DE03 station in Germany. The general evolution of $\mathrm{PM}_{2.5}$ as a function of changes in meteorology is well represented by the model: the correlation coefficients for the simulation and observations have similar profiles, but they differ by about 0.10 . The model correctly reproduces the evolution of $\mathrm{SO}_{4}^{=}$as a function of changes in precipitation and wind speed. The modeled correlations for $\mathrm{PM}_{2.5}$ and its components versus precipitation are between -0.2 and -0.35 at $\mathrm{lag}=0$ or +1 compared to observed correlations between -0.1 and -0.2 also at lag $=0$ or +1 . The modeled correlations for $\mathrm{PM}_{2.5}$ and its components versus wind speed are between -0.4 and -0.5 at lag $=0$ or +1 compared to observed correlations between -0.15 and -0.3 also at lag $=0$ or +1 . The correlations with temperature and precipitation show better agreement for $\mathrm{PM}_{2.5}$ and $\mathrm{SO}_{4}^{=}$than for $\mathrm{NO}_{3}^{-}$and $\mathrm{NH}_{4}^{+} \cdot \mathrm{NO}_{3}^{-}$modeled concentrations are four times greater than the observations, which may be the result of the overestimation of $\mathrm{NO}_{3}^{-}$by the model and/or negative artifacts in the measurements. The model overestimates the correlation between wind speed and $\mathrm{NO}_{3}^{-}$and $\mathrm{NH}_{4}^{+}$, but it correctly reproduces the low correlation between temperature and both $\mathrm{NO}_{3}^{-}$and $\mathrm{NH}_{4}^{+}$. Simulation data show that the positive correlation between temperature and $\mathrm{PM}_{2.5}$ is the result of low positive correlations with $\mathrm{SO}_{4}^{=}(0.05)$, mineral dust (0.20), and organic matter $(0.25)$ and of low negative correlations with $\mathrm{NH}_{4}^{+}(-0.05), \mathrm{NO}_{3}^{-}$ $(-0.05)$, black carbon $(-0.25)$, and sea salt $(-0.15)$. The correlation between $\mathrm{SO}_{4}^{=}$and temperature is positive $(+0.3)$. This result is opposite to those at AT02 and DE02. It reflects the fact that this station is remote from large $\mathrm{SO}_{2}$ emission sources that show strong seasonal variability and that it is impacted by $\mathrm{SO}_{2}$ sources with low seasonal variability (e.g., maritime traffic). The fact that the model correctly reproduces this opposite response suggests that it represents the relationship between meteorology and $\mathrm{SO}_{4}^{=}$formation during long-range transport correctly. The effect of wind speed and precipitation on concentrations of $\mathrm{PM}_{2.5}$ and its components is similar to those at the previous stations.

Figure 8 presents correlations for the IT01 station in Italy. The evolution of $\mathrm{PM}_{2.5}$ as a function of changes in temperature and precipitation is well represented by the model; for wind speed, the correlation coefficient has the same profile for the simulation and observations but differs by around 0.30 with the model overestimating the strength of the anticorrelation. For a lag equal to or greater than 3, the correlation between wind speed and $\mathrm{PM}_{2.5}$ is positive (up to 0.15 for a lag equal to 5). This profile, which differs from the other stations, is driven by $\mathrm{NO}_{3}^{-}$and $\mathrm{NH}_{4}^{+}$and is well represented by 


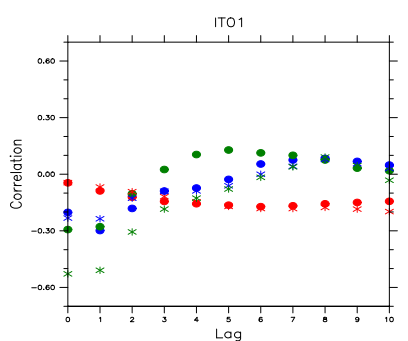

(a) $\mathrm{PM}_{2.5}$

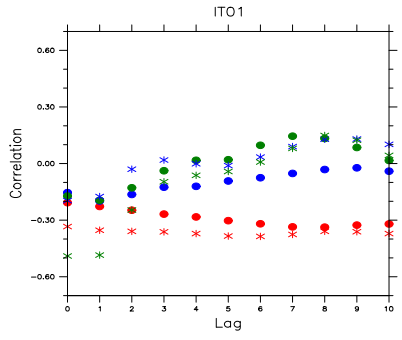

(c) Nitrate

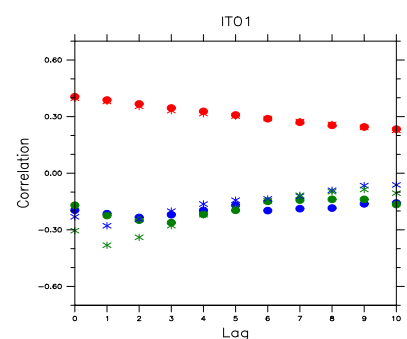

(b) Sulfate

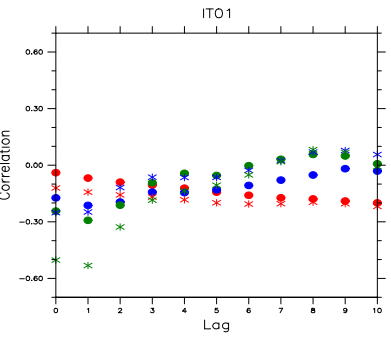

(d) Ammonium
Fig. 8. Correlations between meteorology (temperature in red, precipitation in blue, wind speed in green) on a given day and pollutant concentrations $\left(\mathrm{PM}_{2.5}\right.$, sulfate, nitrate, and ammonium), ranging up to 10 days after at IT01 (2007-2008). Simulated data are represented with a star, while observational data are represented with a dot.

the model. The model correctly reproduces the evolution of $\mathrm{SO}_{4}^{=}, \mathrm{NO}_{3}^{-}$, and $\mathrm{NH}_{4}^{+}$as a function of changes in temperature and precipitation (although the strength of the correlation between precipitation and $\mathrm{NO}_{3}^{-}$is slightly underestimated by the model). The correlation between $\mathrm{SO}_{4}^{=}$and temperature is positive as for DE03 and therefore shows a relationship opposite to that obtained at AT02 and DE02. The model reproduces this correlation perfectly. The model overestimates the strength of the anticorrelation between wind speed and $\mathrm{NH}_{4}^{+}$or $\mathrm{NO}_{3}^{-}$. Simulation data show that the negative correlation between temperature and $\mathrm{PM}_{2.5}$ is driven by $\mathrm{NH}_{4}^{+}$ $(-0.2), \mathrm{NO}_{3}^{-}(-0.35)$, black carbon $(-0.5)$, sea salt $(-0.15)$, and organic matter $(-0.2)$.

Correlations between $\mathrm{NO}_{3}^{-} / \mathrm{NH}_{4}^{+}$and wind speed present large differences between the observations and the simulation at the AT02, DE02, DE03, and IT01 stations. Simulated $\mathrm{NO}_{3}^{-}$is overestimated, which is a recurring issue in PM modeling over Europe. Moreover, there is less $\mathrm{NO}_{3}^{-}$in summer than in winter in the simulation, and significantly less at some stations ( $-63 \%$ AT02, $-20 \%$ at DE02, $-14 \%$ at DE03, and $-56 \%$ at IT01, see Table 4). The correlations obtained with the model are strong and may reflect the availability of daily and gridded data. These strong correlations may not be seen in the observations because of the lower concentrations of $\mathrm{NO}_{3}^{-}$in the measurements, especially in summer, and the fact that observations are not always available everyday.

Figure 9 presents results for the NO01 station in Norway. The evolution of $\mathrm{PM}_{2.5}$ as a function of changes in temper-

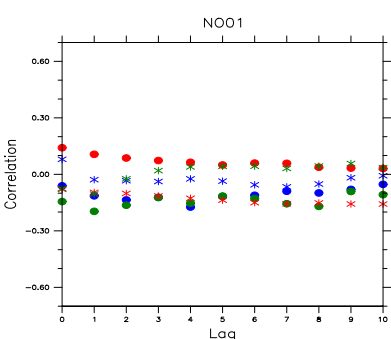

(a) $\mathrm{PM}_{2.5}$

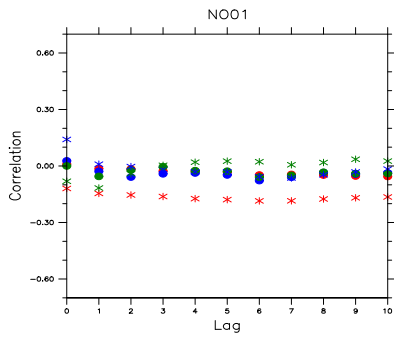

(c) Nitrate

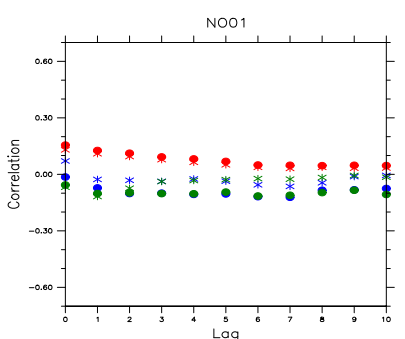

(b) Sulfate

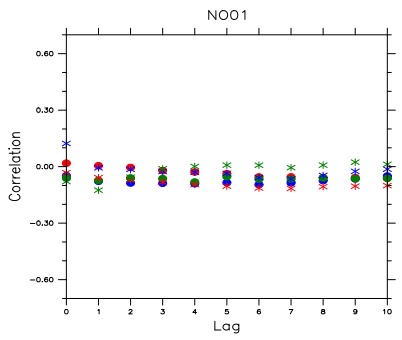

(d) Ammonium
Fig. 9. Correlations between meteorology (temperature in red, precipitation in blue, wind speed in green) on a given day and pollutant concentrations ( $\mathrm{PM}_{2.5}$, sulfate, nitrate, and ammonium), ranging up to 10 days after at NO01 (2002-2008). Simulated data are represented with a star, while observational data are represented with a dot.

ature is not well represented $(0.1$ for the observations versus -0.1 for the simulation as a consequence of the performance for $\mathrm{NO}_{3}^{-}$). In the observations, the dependence of $\mathrm{PM}_{2.5}$ on temperature is driven by that of $\mathrm{SO}_{4}^{=}$and $\mathrm{NH}_{4}^{+}$because $\mathrm{NO}_{3}^{-}$ shows very low correlations. The correlations between $\mathrm{PM}_{2.5}$ and precipitation or wind speed are very low in the observations, which is a major difference with the four other sites. The model correctly reproduces this behavior with negative but low (between -0.15 and 0 ) correlations compared to those obtained at the other stations. The evolution of $\mathrm{SO}_{4}^{=}$ as a function of changes in meteorology is well represented, although the strength of the correlations is slightly overestimated for precipitation and wind speed. NO01 correlations are smaller in absolute value than the correlations at the other stations in both observations and simulation, especially for $\mathrm{NO}_{3}^{-}$and $\mathrm{NH}_{4}^{+}$. This can be explained by the fact that $\mathrm{PM}_{2.5}$ observed mean concentrations at NO01 $\left(4.4 \mu \mathrm{g} \mathrm{m}^{-3}\right)$ are significantly lower than those at most of the other stations $\left(19.9 \mu \mathrm{g} \mathrm{m}^{-3}\right.$ at AT02, $12.9 \mu \mathrm{g} \mathrm{m}^{-3}$ at DE02, $5.9 \mu \mathrm{g} \mathrm{m}^{-3}$ at DE03, and $22 \mu \mathrm{g} \mathrm{m}^{-3}$ at IT01), added to the fact that there are significantly fewer $\mathrm{PM}_{2.5}$ data at the NO01 station compared to the four other sites.

The positive correlations between temperature and $\mathrm{SO}_{4}^{=}$at DE03, IT01, and NO01 suggest that atmospheric oxidation of $\mathrm{SO}_{2}$ (favored by faster kinetics at higher temperatures and greater oxidant concentrations in summer) dominates over greater $\mathrm{SO}_{2}$ emissions (expected with low temperatures in Eastern Europe, see Fig. 6). The fact that there are no large 
sources of emissions around these stations (Fig. 6) and that daily mean concentrations of $\mathrm{SO}_{4}^{=}$are higher in summer $\left(1.5 \mu \mathrm{g} \mathrm{m}^{-3}\right.$ at DE03, $2.0 \mu \mathrm{g} \mathrm{m}^{-3}$ at IT01, and $1.1 \mu \mathrm{g} \mathrm{m}^{-3}$ at NO01) than in winter $\left(1.4 \mu \mathrm{g} \mathrm{m}^{-3}\right.$ at DE03, $1.2 \mu \mathrm{g} \mathrm{m}^{-3}$ at IT01, and $0.9 \mu \mathrm{g} \mathrm{m}^{-3}$ at NO01) comforts this hypothesis.

This dynamic evaluation needed to be performed on stations that provide daily data of $\mathrm{PM}_{2.5}$ and its components for a common period of over at least a year. There requirements were meant to increase the significance of the statistical indicators. Since $\mathrm{PM}_{2.5}$ measurements are relatively recent in Europe, the number of stations meeting these requirements is small, which is a limitation of this study. Therefore, one should be cautious not to extrapolate the model dynamic performance to regions far remote from these stations. Nevertheless, the ability of the model to reproduce the effect of meteorology on $\mathrm{PM}_{2.5}$ and its inorganic components is satisfactorily characterized at several stations, which are located in various parts of Europe and which provide different types of responses.

\section{Conclusions}

A $9 \mathrm{yr}$ air quality simulation has been conducted over Europe with the Polyphemus/Polair3D CTM. The results of the simulation were compared with available EMEP measurements and both an operational/diagnostic evaluation and a dynamic evaluation (with respect to meteorology) were conducted.

Modeled $\mathrm{PM}_{2.5}$ concentrations vary over Europe by a factor of 6 , from high concentrations of $36 \mu \mathrm{g} \mathrm{m}{ }^{-3}$ over northern Italy to low concentrations of $6 \mu \mathrm{g} \mathrm{m}^{-3}$ over Scandinavia). $\mathrm{PM}_{2.5}$ composition varies also significantly. For example, the $\mathrm{PM}_{2.5} \mathrm{SO}_{4}^{=}$fraction is highest in Eastern Europe, the $\mathrm{NO}_{3}^{-}$ fraction is highest in Central Europe, and the organic fraction is highest in Scandinavia, Portugal, eastern France, and Eastern Europe.

The operational/diagnostic evaluation shows that $\mathrm{O}_{3}$ meets the model performance criteria and that $\mathrm{PM}_{2.5}, \mathrm{PM}_{10}$, and $\mathrm{SO}_{4}^{=}$meet the performance goals. $\mathrm{NO}_{3}^{-}$and $\mathrm{NH}_{4}^{+}$are overestimated by the model; $\mathrm{NH}_{4}^{+}$meets the performance criteria, but $\mathrm{NO}_{3}^{-}$does not. The correlation coefficients between simulated and observed data are $63 \%$ for $\mathrm{O}_{3}, 57 \%$ for $\mathrm{PM}_{10}$, $59 \%$ for $\mathrm{PM}_{2.5}, 56.5 \%$ for $\mathrm{SO}_{4}^{=}, 58 \%$ for $\mathrm{NH}_{4}^{+}$, and $42 \%$ for $\mathrm{NO}_{3}^{-}$. The comparison with other recent $1 \mathrm{yr}$ model simulations over Europe shows that all models overestimate $\mathrm{NO}_{3}^{-}$ and that the bias for Polair3D is comparable to the bias for WRF/Chem, but greater to that for CHIMERE. The performance for $\mathrm{PM}_{2.5}, \mathrm{SO}_{4}^{=}$, and $\mathrm{NH}_{4}^{+}$is comparable to that of the other models.

The dynamic evaluation shows that the evolution of $\mathrm{PM}_{2.5}$ as a function of changes in meteorology is well represented for precipitation and wind speed overall, although the model tends to overestimate the $\mathrm{PM}_{2.5}$ response to wind speed. Results are mixed for temperature because of the complex relationships between $\mathrm{PM}_{2.5}$ components and temperature, but the model shows good agreement for half of the $\mathrm{PM}_{2.5}$ stations. The correlations show that the response of $\mathrm{PM}_{2.5}$ to changes in meteorology differs according to the location of the station and the meteorological variable considered. Wind and precipitation show mostly a strong negative correlation with pollutants (except for sea salt, for which a positive correlation is modeled) for lags of 0 or 1 day, and a correlation near 0 with a larger day lag. The correlation coefficient is nearly constant for temperature, for any lag and pollutant species. The response of $\mathrm{PM}_{2.5}$ and $\mathrm{SO}_{4}^{=}$to changes in temperature varies significantly among stations and can be opposite depending on the distance of the station from certain $\mathrm{SO}_{2}$ emission regions with strong seasonality. These different responses are correctly reproduced by the model. The correlation profiles for observed data at the NO01 station differ from those at the other stations; the model also reproduces these differences correctly.

This dynamic evaluation is limited by the amount of data on $\mathrm{PM}_{2.5}$ and its composition over large periods at European stations. For example, the lack of $\mathrm{PM}_{2.5}$ chemical composition data in the western part of the domain (i.e., the countries near the Atlantic Ocean: Ireland, France, the United Kingdom, Spain, and Portugal) is a limitation of this study. The results of studies on the impact of meteorology/climate change on $\mathrm{PM}_{2.5}$ compositions on that westernmost part of Europe should therefore be treated with caution. Analyses of correlation between observed temperature and $\mathrm{NO}_{3}^{-}$concentrations in the US have shown results that differed from modeled responses of $\mathrm{NO}_{3}^{-}$to temperature (Tai et al., 2010). Such analyses in Europe would require conducting the dynamic evaluation by season; however, the observational data set is not sufficient to conduct a meaningful statistical analysis by season. Furthermore, it would be interesting to extend this analysis to carbonaceous $\mathrm{PM}_{2.5}$, particulary since particulate organic matter displays a complex relationship to temperature. As the monitoring of $\mathrm{PM}_{2.5}$ with chemical speciation increases over Europe, further dynamic evaluations should be conducted to test the ability of air quality models to reproduce the effect of meteorology on $\mathrm{PM}_{2.5}$ concentrations and composition. Nevertheless, the results of this study provide the first dynamic evaluation on an $\mathrm{PM}_{2.5}$ air quality model with respect to meteorology. 


\section{Appendix A}

Comparison with other modeling studies in the context of AQMEII

Table A1. Comparisons to observations for surface $\mathrm{PM}_{10}$ and $\mathrm{PM}_{2.5}$ over Europe (concentrations and RMSE are in $\mu \mathrm{g} \mathrm{m}^{-3}$ ) from $7 \mathrm{July}$ to 31 August for this simulation (2000-2008) and the AQMEII models (2006) (Sartelet et al., 2012).

\begin{tabular}{|c|c|c|c|c|c|c|c|c|}
\hline & \multicolumn{4}{|c|}{$\mathrm{PM}_{10}$} & \multicolumn{4}{|c|}{$\mathrm{PM}_{2.5}$} \\
\hline & \multirow[t]{2}{*}{ This work } & \multicolumn{3}{|c|}{ AQMEII models } & \multirow[t]{2}{*}{ This work } & \multicolumn{3}{|c|}{ AQMEII models } \\
\hline & & Min & Mean & Max & & Min & Mean & Max \\
\hline Number of stations & 12 & 235 & 235 & 235 & 7 & 39 & 39 & 39 \\
\hline Mean observed & 15.9 & 23.2 & 23.2 & 23.2 & 11.5 & 13.3 & 13.3 & 13.3 \\
\hline Mean simulated & 16.6 & 6.2 & 12.9 & 23.4 & 16 & 5 & 12.3 & 21.4 \\
\hline RMSE & 7.7 & 16.2 & 23.2 & 24.6 & 7.2 & 11.4 & 24.1 & 69.2 \\
\hline Correlation & $57.3 \%$ & $8.2 \%$ & $17.3 \%$ & $25 \%$ & $67.6 \%$ & $3.2 \%$ & $11.8 \%$ & $21.1 \%$ \\
\hline MFB & $7.6 \%$ & $-111.0 \%$ & $-64.3 \%$ & $3.9 \%$ & $32.7 \%$ & $-85.7 \%$ & $-30.5 \%$ & $44.9 \%$ \\
\hline MFE & $35.4 \%$ & $44.5 \%$ & $80.8 \%$ & $113 \%$ & $43.4 \%$ & $55.1 \%$ & $72.3 \%$ & $94.2 \%$ \\
\hline
\end{tabular}

\section{Appendix B}

\section{Comparison with model performance evaluations of $1 \mathrm{yr}$ simulations over Europe}

Table B1. Comparison for $\mathrm{PM}_{2.5}$ with Péré et al. (2010), Pay et al. (2010), Tuccella et al. (2012), and Appel et al. (2012). The data from this work are averaged over 2000-2008.

\begin{tabular}{lrrrrr}
\hline $\begin{array}{l}\text { References } \\
\text { Models }\end{array}$ & $\begin{array}{r}\text { Péré et al. } \\
\text { CHIMERE } \\
\text { Year(s) simulated }\end{array}$ & $\begin{array}{r}\text { Pay et al. } \\
\text { CALIOPE-EU } \\
(2004)\end{array}$ & $\begin{array}{r}\text { Tucella et al. } \\
\text { WRF/Chem } \\
(2007)\end{array}$ & $\begin{array}{r}\text { Appel et al. } \\
\text { CMAQ } \\
(2006)\end{array}$ & $\begin{array}{r}\text { This work } \\
\text { Polair3D }\end{array}$ \\
\hline Number of stations & 11 & 16 & NA & 160 & 22 \\
Obs $\left(\mu \mathrm{g} \mathrm{m}^{-3}\right)$ & 12.2 & 13.0 & 12.6 & & 13.3 \\
Sim $\left(\mu \mathrm{g} \mathrm{m}^{-3}\right)$ & 15.1 & 6.3 & 8.6 & & 15.9 \\
Correlation $(\%)$ & 73 & 45 & 41 & & 59 \\
RMSE $\left(\mu \mathrm{g} \mathrm{m}^{-3}\right)$ & & 11.6 & & & 9 \\
MFB $(\%)$ & & -74 & & & 29.8 \\
MFE $(\%)$ & & & & & 47.7 \\
MNB $(\%)$ & & & -7.3 & & 62 \\
MNE $(\%)$ & & 59.6 & & 76 \\
NMB $(\%)$ & 24.2 & & & -46.6 & 26.4 \\
NME $(\%)$ & & & 55.2 & 53.1 \\
\hline
\end{tabular}

Table B2. Comparison for sulfate with Péré et al. (2010) and Tuccella et al. (2012). The data from this work are averaged over 20002008 .

\begin{tabular}{|c|c|c|c|}
\hline $\begin{array}{l}\text { References } \\
\text { Models } \\
\text { Year(s) simulated }\end{array}$ & $\begin{array}{r}\text { Péré et al. } \\
\text { CHIMERE } \\
(2003)\end{array}$ & $\begin{array}{r}\text { Tucella et al. } \\
\text { WRF/Chem } \\
(2007)\end{array}$ & $\begin{array}{r}\text { This work } \\
\text { Polair3D } \\
\text { (averaged 2000-2008) }\end{array}$ \\
\hline Number of stations & 11 & NA & 77 \\
\hline Obs $\left(\mu \mathrm{g} \mathrm{m}^{-3}\right)$ & 3.9 & 2.4 & 2.3 \\
\hline $\operatorname{Sim}\left(\mu \mathrm{g} \mathrm{m}^{-3}\right)$ & 4.0 & 0.9 & 2.2 \\
\hline Correlation (\%) & 50 & 50 & 56 \\
\hline MNB (\%) & & -46.9 & 16.6 \\
\hline $\operatorname{MNE}(\%)$ & & 64.9 & 51.3 \\
\hline NMB (\%) & 4.25 & & 4.5 \\
\hline
\end{tabular}

Table B3. Comparison for nitrate with Péré et al. (2010) and Tuccella et al. (2012). The data from this work are averaged over 20002008.

\begin{tabular}{lrrr}
\hline $\begin{array}{l}\text { References } \\
\text { Models }\end{array}$ & $\begin{array}{r}\text { Péré et al. } \\
\text { CHIMERE } \\
\text { Year(s) simulated }\end{array}$ & $\begin{array}{r}\text { Tucella et al. } \\
\text { WRF/Chem } \\
(2007)\end{array}$ & $\begin{array}{r}\text { This work } \\
\text { Polair3D }\end{array}$ \\
\hline Number of stations & 11 & NA & 33 \\
Obs $\left(\mu \mathrm{g} \mathrm{m}^{-3}\right)$ & 3.1 & 2.9 & 2 \\
Sim $\left(\mu \mathrm{g} \mathrm{m}^{-3}\right)$ & 4.6 & 4.4 & 3.6 \\
Correlation $(\%)$ & 59 & 48 & 42 \\
MNB $(\%)$ & & 115.2 & 123.8 \\
MNE $(\%)$ & & 169.3 & 163.7 \\
NMB $(\%)$ & 36.7 & & 112.2 \\
\hline
\end{tabular}


Table B4. Comparison for ammonium with Péré et al. (2010) and Tuccella et al. (2012). The data from this work are averaged over 2000-2008.

\begin{tabular}{|c|c|c|c|}
\hline $\begin{array}{l}\text { References } \\
\text { Models } \\
\text { Year(s) simulated }\end{array}$ & $\begin{array}{r}\text { Péré et al. } \\
\text { CHIMERE } \\
(2003)\end{array}$ & $\begin{array}{r}\text { Tucella et al. } \\
\text { WRF/Chem } \\
(2007)\end{array}$ & $\begin{array}{r}\text { This work } \\
\text { Polair3D } \\
\text { (averaged 2000-2008) }\end{array}$ \\
\hline Number of stations & 11 & NA & 34 \\
\hline Obs $\left(\mu \mathrm{g} \mathrm{m}^{-3}\right)$ & 2.1 & 1.8 & 0.9 \\
\hline $\operatorname{Sim}\left(\mu \mathrm{g} \mathrm{m}^{-3}\right)$ & 3.1 & 1.7 & 1.4 \\
\hline Correlation (\%) & 60 & 57 & 58 \\
\hline MNB (\%) & & 96.4 & 59.9 \\
\hline $\operatorname{MNE}(\%)$ & & 139 & 86.2 \\
\hline NMB (\%) & 48.5 & & 47.7 \\
\hline
\end{tabular}

Edited by: J. Brandt

\section{References}

Appel, K., Chemel, C., Roselle, S. R., Francis, X., Hu, R.-M., Sokhi, R., Rao, S., and Galmarini, S.: Examination of the Community Multiscale Air Quality (CMAQ) model performance over the North American and European domains, Atmos. Environ., 53, 142-155, doi:10.1016/j.atmosenv.2011.11.016, 2012.

Avise, J., Chen, J., Lamb, B., Wiedinmyer, C., Guenther, A., Salathé, E., and Mass, C.: Attribution of projected changes in summertime US ozone and $\mathrm{PM}_{2.5}$ concentrations to global changes, Atmos. Chem. Phys., 9, 1111-1124, doi:10.5194/acp9-1111-2009, 2009.

Boylan, J. W. and Russell, A. G.: PM and light extinction model performance metrics, goals, and criteria for threedimensional air quality models, Atmos. Environ., 40, 49464959, doi:10.1016/j.atmosenv.2005.09.087, 2006.

Chen, J., Avise, J., Lamb, B., Salathé, E., Mass, C., Guenther, A., Wiedinmyer, C., Lamarque, J.-F., O'Neill, S., McKenzie, D., and Larkin, N.: The effects of global changes upon regional ozone pollution in the United States, Atmos. Chem. Phys., 9, 11251141, doi:10.5194/acp-9-1125-2009, 2009.

Colette, A., Granier, C., Hodnebrog, Ø., Jakobs, H., Maurizi, A., Nyiri, A., Bessagnet, B., D’Angiola, A., D’Isidoro, M., Gauss, M., Meleux, F., Memmesheimer, M., Mieville, A., Rouil, L., Russo, F., Solberg, S., Stordal, F., and Tampieri, F.: Air quality trends in Europe over the past decade: a first multi-model assessment, Atmos. Chem. Phys., 11, 11657-11678, doi:10.5194/acp11-11657-2011, 2011.

Couvidat, F., Debry, É., Sartelet, K., and Seigneur, C.: A hydrophilic/hydrophobic organic $\left(\mathrm{H}^{2} \mathrm{O}\right)$ model: Model development, evaluation and sensitivity analysis, J. Geophys. Res., 117, D10304, doi:10.1029/2011JD017214, 2012.

Couvidat, F., Kim, Y., Sartelet, K., Seigneur, C., Marchand, N., and Sciare, J.: Modeling secondary organic aerosol in an urban area: application to Paris, France, Atmos. Chem. Phys., 13, 983-996, doi:10.5194/acp-13-983-2013, 2013.

Dawson, J. P., Adams, P. J., and Pandis, S. N.: Sensitivity of $\mathrm{PM}_{2.5}$ to climate in the Eastern US: a modeling case study, Atmos. Chem. Phys., 7, 4295-4309, doi:10.5194/acp-7-4295-2007, 2007.
Dawson, J. P., Racherla, P. N., Lynn, B. H., Adams, P. J., and Pandis, S. N.: Impacts of climate change on regional and urban air quality in the eastern United States: Role of meteorology, J. Geophys. Res., 114, D05308, doi:10.1029/2008JD009849, 2009.

Debry, E., Fahey, K., Sartelet, K., Sportisse, B., and Tombette, M.: Technical Note: A new SIze REsolved Aerosol Model (SIREAM), Atmos. Chem. Phys., 7, 1537-1547, doi:10.5194/acp-7-1537-2007, 2007.

Dennis, R., Fox, T., Fuentes, M., Gilliland, A., Hanna, S., Hogrefe, C., Irwin, J., Rao, S., Scheffe, R., Schere, K., Steyn, D., and Venkatram, A.: A framework for evaluating regionalscale numerical photochemical modeling systems, Environmental Fluid Mechanics, 10, 471-489, doi:10.1007/s10652-0099163-2, 2010.

Emmons, L. K., Walters, S., Hess, P. G., Lamarque, J.-F., Pfister, G. G., Fillmore, D., Granier, C., Guenther, A., Kinnison, D., Laepple, T., Orlando, J., Tie, X., Tyndall, G., Wiedinmyer, C., Baughcum, S. L., and Kloster, S.: Description and evaluation of the Model for Ozone and Related chemical Tracers, version 4 (MOZART-4), Geosci. Model Dev., 3, 43-67, doi:10.5194/gmd3-43-2010, 2010.

EPA: Guideline for regulatory application of the urban airshed model, Tech. rep., EPA, 1991.

Galindo, N., Varea, M., Gil-Moltó, J., Yubero, E., and Nicolás, J.: The Influence of Meteorology on Particulate Matter Concentrations at an Urban Mediterranean Location, Water Air Soil Pollut., 215, 365-372, doi:10.1007/s11270-010-0484-z, 2011.

Gilliland, A. B., Hogrefe, C., Pinder, R. W., Godowitch, J. M., Foley, K. L., and Rao, S.: Dynamic evaluation of regional air quality models: Assessing changes in $\mathrm{O} 3$ stemming from changes in emissions and meteorology, Atmos. Environ., 42, 5110-5123, doi:10.1016/j.atmosenv.2008.02.018, 2008.

Guenther, A., Karl, T., Harley, P., Wiedinmyer, C., Palmer, P. I., and Geron, C.: Estimates of global terrestrial isoprene emissions using MEGAN (Model of Emissions of Gases and Aerosols from Nature), Atmos. Chem. Phys., 6, 3181-3210, doi:10.5194/acp-63181-2006, 2006.

Hering, S. and Cass, G.: The Magnitude of Bias in the Measurement of PM25 Arising from Volatilization of Particulate Nitrate from Teflon Filters, J. Air Waste Manage. Assoc., 49, 725-733, doi:10.1080/10473289.1999.10463843, 1999.

Katragkou, E., Zanis, P., Kioutsioukis, I., Tegoulias, I., Melas, D., Krüger, B., and Coppola, E.: Future climate change impacts on summer surface ozone from regional climate-air quality simulations over Europe, J. Geophys. Res., 116, D22307, doi:10.1029/2011JD015899, 2011.

Kelly, J., Makar, P. A., and Plummer, D. A.: Projections of mid-century summer air-quality for North America: effects of changes in climate and precursor emissions, Atmos. Chem. Phys., 12, 5367-5390, doi:10.5194/acp-12-5367-2012, 2012.

Kim, Y., Sartelet, K., and Seigneur, C.: Comparison of two gasphase chemical kinetic mechanisms of ozone formation over Europe, J. Atmos. Chem., 62, 89-119, doi:10.1007/s10874-0099142-5, 2009.

Loon, M. V., Vautard, R., Schaap, M., Bergström, R., Bessagnet, B., Brandt, J., Builtjes, P., Christensen, J., Cuvelier, C., Graff, A., Jonson, J., Krol, M., Langner, J., Roberts, P., Rouil, L., Stern, R., Tarrasón, L., Thunis, P., Vignati, E., White, L., and Wind, P.: Evaluation of long-term ozone simulations from seven re- 
gional air quality models and their ensemble, Atmos. Environ., 41, 2083-2097, doi:10.1016/j.atmosenv.2006.10.073, 2007.

Mahmud, A., Tyree, M., Cayan, D., Motallebi, N., and Kleeman, M. J.: Statistical downscaling of climate change impacts on ozone concentrations in California, J. Geophys. Res., 113, D21103, doi:10.1029/2007JD009534, 2008.

Mahmud, A., Hixson, M., Hu, J., Zhao, Z., Chen, S.-H., and Kleeman, M. J.: Climate impact on airborne particulate matter concentrations in California using seven year analysis periods, Atmos. Chem. Phys., 10, 11097-11114, doi:10.5194/acp10-11097-2010, 2010.

Mahowald, N. M., Lamarque, J.-F., Tie, X. X., and Wolff, E.: Seasalt aerosol response to climate change: Last Glacial Maximum, preindustrial, and doubled carbon dioxide climates, J. Geophys. Res.-Atmos., 111, D05303, doi:10.1029/2005JD006459, 2006.

Mallet, V., Quélo, D., Sportisse, B., Ahmed de Biasi, M., Debry, É., Korsakissok, I., Wu, L., Roustan, Y., Sartelet, K., Tombette, M., and Foudhil, H.: Technical Note: The air quality modeling system Polyphemus, Atmos. Chem. Phys., 7, 5479-5487, doi:10.5194/acp-7-5479-2007, 2007.

Meleux, F., Solmon, F., and Giorgi, F.: Increase in summer European ozone amounts due to climate change, Atmos. Environ., 41, 7577-7587, doi:10.1016/j.atmosenv.2007.05.048, 2007.

Monahan, E., Spiel, D., and Davidson, K.: A model of marine aerosol generation via whitecaps and wave disruption, in: Oceanic whitecaps and their role in sea-air exchange processes, Dordrecht, D. Reidel, 167-174, 1986.

Nenes, A., Pandis, S., and Pilinis, C.: ISORROPIA: A new thermodynamic equilibrium model for multiphase multicomponent inorganic aerosols, Aquat. Geoch., 4, 123-152, 1998.

Pay, M., Piot, M., Jorba, O., Gassó, S., Gonçalves, M., Basart, S., Dabdub, D., Jiménez-Guerrero, P., and Baldasano, J.: A full year evaluation of the CALIOPE-EU air quality modeling system over Europe for 2004, Atmos. Environ., 44, 3322-3342, doi:10.1016/j.atmosenv.2010.05.040, 2010.

Péré, J., Mallet, M., Pont, V., and Bessagnet, B.: Evaluation of an aerosol optical scheme in the chemistrytransport model CHIMERE, Atmos. Environ., 44, 3688-3699, doi:10.1016/j.atmosenv.2010.06.034, 2010.

Pye, H. O. T., Liao, H., Wu, S., Mickley, L. J., Jacob, D. J., Henze, D. K., and Seinfeld, J. H.: Effect of changes in climate and emissions on future sulfate-nitrate-ammonium aerosol levels in the United States, J. Geophys. Res., 114, D01205, doi:10.1029/2008JD010701, 2009.

Racherla, P. N. and Adams, P. J.: Sensitivity of global tropospheric ozone and fine particulate matter concentrations to climate change, J. Geophys. Res., 111, D24103, doi:10.1029/2005JD006939, 2006.

Russell, A. and Dennis, R.: NARSTO critical review of photochemical models and modeling, Atmos. Environ., 34, 2283-2324, doi:10.1016/S1352-2310(99)00468-9, 2000.

Sartelet, K., Debry, E., Fahey, K., Roustan, Y., Tombette, M., and Sportisse, B.: Simulation of aerosols and gas-phase species over Europe with the Polyphemus system: Part I - Model-todata comparison for 2001, Atmos. Environ., 41, 6116-6131, doi:10.1016/j.atmosenv.2007.04.024, 2007.

Sartelet, K. N., Couvidat, F., Seigneur, C., and Roustan, Y.: Impact of biogenic emissions on air quality over Europe and North America, Atmos. Environ., 53, 131-141, doi:10.1016/j.atmosenv.2011.10.046, 2012.

Schaap, M., Spindler, G., Schulz, M., Acker, K., Maenhaut, W., Berner, A., Wieprecht, W., Streit, N., Müller, K., Brüggemann, E., Chi, X., Putaud, J.-P., Hitzenberger, R., Puxbaum, H., Baltensperger, U., and ten Brink, H.: Artefacts in the sampling of nitrate studied in the INTERCOMP campaigns of EUROTRAC-AEROSOL, Atmos. Environ., 38, 6487-6496, doi:10.1016/j.atmosenv.2004.08.026, 2004.

Seigneur, C., Pun, B., Pai, P., Louis, J.-F., Solomon, P., Emery, C., Morris, R., Zahniser, M., Worsnop, D., Koutrakis, P., White, W., and Tombach, I.: Guidance for the Performance Evaluation of Three-Dimensional Air Quality Modeling Systems for Particulate Matter and Visibility, J. Air Waste Manage. Assoc., 50, 588599, doi:10.1080/10473289.2000.10464036, 2000.

Singh, A. and Palazoglu, A.: Climatic variability and its influence on ozone and PM pollution in 6 non-attainment regions in the United States, Atmos. Environ., 51, 212-224, doi:10.1016/j.atmosenv.2012.01.020, 2012.

Solazzo, E., Bianconi, R., Pirovano, G., Matthias, V., Vautard, R., Moran, M. D., Appel, K. W., Bessagnet, B., Brandt, J., Christensen, J. H., Chemel, C., Coll, I., Ferreira, J., Forkel, R., Francis, X. V., Grell, G., Grossi, P., Hansen, A. B., Miranda, A. I., Nopmongcol, U., Prank, M., Sartelet, K. N., Schaap, M., Silver, J. D., Sokhi, R. S., Vira, J., Werhahn, J., Wolke, R., Yarwood, G., Zhang, J., Rao, S. T., and Galmarini, S.: Operational model evaluation for particulate matter in Europe and North America in the context of AQMEII, Atmos. Environ., 53, 75-92, doi:10.1016/j.atmosenv.2012.02.045, 2012.

Tagaris, E., Liao, K.-J., DeLucia, A. J., Deck, L., Amar, P., and Russell, A. G.: Potential Impact of Climate Change on Air PollutionRelated Human Health Effects, Environ. Sci. Technol., 43, 49794988, doi:10.1021/es803650w, 2009.

Tai, A. P., Mickley, L. J., and Jacob, D. J.: Correlations between fine particulate matter (PM2.5) and meteorological variables in the United States: Implications for the sensitivity of PM2.5 to climate change, Atmos. Environ., 44, 3976-3984, doi:10.1016/j.atmosenv.2010.06.060, 2010.

Tai, A. P. K., Mickley, L. J., Jacob, D. J., Leibensperger, E. M., Zhang, L., Fisher, J. A., and Pye, H. O. T.: Meteorological modes of variability for fine particulate matter $\left(\mathrm{PM}_{2.5}\right)$ air quality in the United States: implications for $\mathrm{PM}_{2.5}$ sensitivity to climate change, Atmos. Chem. Phys., 12, 3131-3145, doi:10.5194/acp12-3131-2012, 2012.

Troen, I. B. and Mahrt, L.: A simple model of the atmospheric boundary layer; sensitivity to surface evaporation, Bound.-Lay. Meteorol., 37, 129-148, doi:10.1007/BF00122760, 1986.

Tuccella, P., Curci, G., Visconti, G., Bessagnet, B., Menut, L., and Park, R.: Modeling of gas and aerosol with WRF/Chem over Europe: Evaluation and sensitivity study, J. Geophys. Res, 117, D03303, doi:10.1029/2011JD016302, 2012.

Wild, O., Zhu, X., and Prather, M. J.: Fast-J: Accurate Simulation of In- and Below-Cloud Photolysis in Tropospheric Chemical Models, J. Atmos. Chem., 37, 245-282, doi:10.1023/A:1006415919030, 2000.

Wu, S., Mickley, L. J., Leibensperger, E. M., Jacob, D. J., Rind, D., and Streets, D. G.: Effects of 2000-2050 global change on ozone air quality in the United States, J. Geophys. Res., 113, D06302, doi:10.1029/2007JD008917, 2008. 
Yarwood, G., Stoeckenius, T. E., Heiken, J. G., and Dunker, A. M.: Modeling Weekday/Weekend Ozone Differences in the Los Angeles Region for 1997, J. Air Waste Manage. Assoc., 53, 864875, doi:10.1080/10473289.2003.10466232, 2003.

Yarwood, G., Morris, R. E., Yocke, M. A., and Whitten, G. Z.: Updates to the Carbon Bond chemical mechanism: CB05. Final Report prepared for US EPA, Tech. rep., US EPA, 2005.

Yttri, K. E., Aas, W., Bjerke, A., Cape, J. N., Cavalli, F., Ceburnis, D., Dye, C., Emblico, L., Facchini, M. C., Forster, C., Hanssen, J. E., Hansson, H. C., Jennings, S. G., Maenhaut, W., Putaud, J. P., and Tørseth, K.: Elemental and organic carbon in $\mathrm{PM}_{10}$ : a one year measurement campaign within the European Monitoring and Evaluation Programme EMEP, Atmos. Chem. Phys., 7, 5711-5725, doi:10.5194/acp-7-5711-2007, 2007.
Zhang, L., Brook, J. R., and Vet, R.: A revised parameterization for gaseous dry deposition in air-quality models, Atmos. Chem. Phys., 3, 2067-2082, doi:10.5194/acp-3-2067-2003, 2003.

Zhang, Y., Hu, X.-M., Leung, L. R., and Gustafson, William I., J.: Impacts of regional climate change on biogenic emissions and air quality, J. Geophys. Res., 113, D18310, doi:10.1029/2008JD009965, 2008. 